\title{
A presença indígena no vale do Rio Tibagi/PR no início do século $X X^{*}$
}

\author{
Indigenous populations and white people in the River Tibagi \\ basin in the early 20th century
}

Lúcio Tadeu Mota ${ }^{1}$

\section{RESUMO}

Com o fim do Império e a instalação da República, as populações indígenas tiveram que reformular suas ações e reinventar novas formas de lidar com o poder do Estado. Esse processo, se por um lado garantiu a sua existência, por outro fez com que eles tivessem que readequar seus modos de vida tradicionais às novas situações. Pretende-se aqui apresentar a situação das populações indígenas presentes na bacia do médio Rio Tibagi no Estado do Paraná. Será destacada a situação histórica da região por volta de 1910, momento da criação do Serviço de Proteção aos Índios e Localização de Trabalhadores Nacionais (SPILTN) e o papel desse órgão na região intermediando as relações entre os indígenas e os nacionais. As populações indígenas envolvidas nesse processo desenvolveram estratégias políticas apropriadas e específicas para contrapor as políticas e as ações de redução de seus territórios. Serão demonstradas as complexas relações históricas e socioculturais que existiram nesse processo, que vão além das explicações oficiais de transformação (aculturação) das populações indígenas em populações rurais, e também evitada a armadilha da história polarizada que simplifica essas relações entre populações diferenciadas.

Palavras-chave: Etno-História indigena. História do Paraná. Serviço de Proteção aos Índios. Fronteiras e populações. Relações socioculturais.

\section{ABSTRACT}

The demise of the Brazilian Empire and the establishment of the Republic in 1889 caused the Brazilian Indians to reformulate their activities and reinvent their methods in their dealings with state power. If, on

* Pesquisa financiada pela Fundação Araucária na modalidade Bolsa de Produtividade em Pesquisa no ano de 2012.

1 Doutor em História pela Unesp-Assis e pesquisador no Laboratório de Arqueologia, Etnologia e Etno-História da Universidade Estadual de Maringá, Brasil. http://www.dhi.uem.br/laee/ 
the one hand, this process warranted their survival, on the other hand, they were forced to adequate their traditional way of life to the new situation. Current paper describes the situation of indigenous populations in the middle Tibagi River basin, state of Paraná, Brazil. The region's historical conditions around the 1910s are underscored within the context of the establishment of the Protection Service to Indians and the Localization of Indigene Workers (SPILTN). The Indigenous populations involved in the process developed proper and specific strategic policies to counteract the government's policy and activities endeavoring to shrink their territories. The complex historical and social and cultural relationships in the process will be provided. In fact, they go beyond the official explanations for the transformation (acculturation) of indigenous populations into rural populations and avoid the ambivalence brought about by polarized history which simplified relationships among differentiated populations.

Keyword: Indigenous ethnohistory. Regional history. Indian Protection Service. Frontiers and populations. Social and cultural relationships.

\section{Introdução}

Pretende-se aqui problematizar a situação das populações indígenas presentes na bacia do médio Rio Tibagi no Estado do Paraná no início do século XX. Esse é o momento da criação do Serviço de Proteção aos Índios e Localização de Trabalhadores Nacionais (SPILTN) e da presença desse órgão na região intermediando as relações entre os indígenas e os nacionais. Nesse período, os povos indígenas Kaingang, Guarani e Kayowá que ali viviam lutavam pela defesa de seus territórios e seus modos de vida numa relação desigual e combinada com as novas relações socioeconômicas capitalistas que chegavam à região.

Procurar-se-á demonstrar as complexas relações históricas e socioculturais que enredavam esse processo. Buscar-se-á ir além das explicações oficiais de transformação (aculturação) das populações indígenas em populações rurais, e também evitar a armadilha da história polarizada que simplifica as relações entre populações diferenciadas.

A literatura sobre os povos indígenas existentes no Sul do Brasil - os Guarani e os Xetá falantes de línguas da família Tupi-Guarani, e os Kaingang e os Xokleng falantes de línguas da família Jê - são fartas em informações sobre seus costumes, modos de vida, cultura material, cosmogonias e história de suas relações com a sociedade envolvente. Essa massa de informações indica que eles habitavam os vastos territórios que iam do Rio Tietê, em São Paulo, ao Rio da Prata ao sul, e do Oceano Atlântico ao Rio Paraná. Com seus etnoconhecimentos manejavam os diversos ambientes da região: desde as áreas de mangue no litoral, até as florestas nas serras e os campos no planalto. Suas economias eram sustentadas nas atividades combinadas de caça, pesca, coleta e agricultura. 
Registros de viajantes, exploradores e a própria memória dos velhos de muitas dessas comunidades fornecem indicações sobre a vasta biodiversidade dos seus hábitats, de sua rica fauna e flora, de seus rios abundantes em peixes, e a fertilidade de suas roças. A documentação e os relatos orais dos idosos reafirmam a qualidade de vida de seus antepassados. Ela era possível graças à diversidade dos recursos naturais proporcionados pelos ecossistemas das bacias fluviais dos rios e das áreas de campos, faxinais e florestas de araucária do planalto, que forneciam alimentos e matérias-primas para atender a todas as suas necessidades vitais e simbólicas.

A arqueologia e a história dessas populações mostram a complexidade dos processos de ocupação dos territórios no vale do Rio Tibagi. Mostra disputas por territórios, deslocamentos, reacomodações de suas moradias nas áreas preferenciais de coleta, caça e agricultura. Processos que ocorriam desde antes do contato com os europeus como registra a arqueologia e continuaram após o contato, conforme fontes da cultura material e a documentação gerada a partir de 1500 .

No entanto, esse processo acelerou-se com a construção do Estado nacional durante o período imperial e tomou um impulso nunca até então visto com o advento da República. ${ }^{2}$

Nesse início da República, as populações indígenas tiveram que reformular suas ações e reinventar novas formas de lidar com o poder do Estado. Não era mais o poder do Império com sua política de "catequese e civilização", com as quais já lidavam desde a implantação das Colônias Indígenas em meados do século XIX. Nessa nova conjuntura, tinham que se relacionar com o poder republicano que havia enfrentado a Revolução Federalista no Sul do País, com reflexos trágicos aqui no Paraná, e a Guerra de Canudos no Nordeste ainda não cicatrizada. Teriam que se relacionar com novas estruturas organizacionais laicas e militares diferentes das religiosas do período imperial. Mais ainda, teriam que se defrontar com as políticas do Estado do Paraná que agora tinha o poder de distribuir as terras em que viviam. $^{3}$

As ações do governo estadual do Paraná e do governo federal confiscavam os territórios indígenas para distribuição em projetos de colonização, estabelecimentos de cidades e vilas. Esse confisco, somado às invasões implementadas pelas populações não indígenas que

2 Sobre o período imperial, ver: Lúcio Tadeu MOTA. As colônias indígenas no Paraná provincial. 1. ed. Curitiba: Aos quatro ventos, 2000. v. 500. 200 p.; Lúcio Tadeu MOTA. O Instituto Histórico e Geográfico Brasileiro e as propostas de integração das comunidades indígenas no Estado nacional. Diálogos. Revista do Departamento de História da Universidade Estadual de Maringá, Maringá, v. 2, n. 2, p. 149-175, 1998. Ainda sobre a política indigenista durante o período imperial, ver o texto de Manuela Carneiro da CUNHA. Política indigenista no século XIX. In História dos índios no Brasil. São Paulo: Cia. das Letras, 1992; a tese de doutorado de Carlos de Araújo MOREIRA NETO. A política indigenista brasileira durante o século XIX. Rio Claro, 1971; o texto de Darcy RIBEIRO. Política indigenista brasileira. Rio de Janeiro: Ministério da Agricultura, 1962.

3 Sobre essa questão das terras "devolutas" passarem para o poder dos Estados, ver o Artigo 64 da Constituição Federal de 1891. Existe uma extensa bibliografia sobre a questão da terra no Império e na República que não cabe aqui listar. Especificamente sobre a questão da terra e os índios, ver José Maria de PAULA. Terra dos Índios. Rio de Janeiro: Ministério da Agricultura, 1944. 
chegavam às áreas de fronteiras, fez com que os povos indígenas implementassem estratégias de sobrevivência e defesa do que restava de seus territórios.

Esse processo, se por um lado garantiu a sua existência no médio Rio Tibagi, por outro fez com que eles tivessem que readequar seus modos de vida tradicionais às novas situações. O wãxi, tempo antigo, se transformou no uri, tempo atual, como afirmam os Kaingang.

A administração das terras consideradas "devolutas", em que se situavam os territórios indígenas, pelos Estados da federação desde a Constituição de 1891, o fim da política imperial de catequese e civilização dos índios com o fechamento das Colônias Indígenas, e o avanço das frentes de ocupação para as áreas de fronteira, potencializadas pela política de negociação de terras pelo Estado do Paraná, acirraram as disputas pela terra e suas riquezas e criaram uma nova conjuntura de lutas que perpassou toda a primeira metade do século XX.

Em meio a essa conjuntura, foi criado em 1910 o Serviço de Proteção aos Índios e Localização dos Trabalhadores Nacionais ${ }^{4}$ (SPILTN). Ele tinha como missão a proteção das populações indígenas. Imediatamente após sua criação, o Serviço passou a atuar no Paraná com a instalação da $7^{\mathrm{a}}$ Inspetoria Regional em Curitiba e a nomeação do capitão José Ozório, do setor de engenharia do exército nacional, para chefiá-la. A primeira ação do Serviço foi inspecionar a situação complexa e conflituosa existente entre os índios e as populações nacionais no vale do Rio Tibagi no norte do Estado. Resultante dessa viagem de inspeção foi gerado o primeiro relatório da situação ali encontrada e a primeira proposição do Serviço: a criação da Povoação Indígena de São Jerônimo.

\section{A instalação SPILTN no Paraná}

Instituído com o objetivo de prestar assistência aos índios e alocar trabalhadores nacionais em centros agrícolas, o Serviço de Proteção aos Índios (SPI) estava subordinado ao Ministério da Agricultura, Indústria e Comércio, e passou a ser dirigido por Cândido Mariano da Silva Rondon, idealizador e implementador do Serviço. ${ }^{5}$

4 Será utilizada daqui em diante a expressão Serviço como referência ao SPILTN

5 A questão dos indígenas já era de responsabilidade do Ministério da Agricultura desde a sua criação em 1906 . Ver o Decreto $\mathrm{n}^{\circ}$ 1.606, de 29/12/1906. O Decreto 8.072 sofreu uma nova regulamentação em fins de 1911 com o Decreto 9.214 de 15 de dezembro de 1911. Em 1918, o SPILTN foi reorganizado, deixando de ser responsável pela questão da Localização dos Trabalhadores Nacionais, e passou a cuidar somente dos povos indígenas, sendo renomeado apenas por Serviço de Proteção aos Índios (SPI) na Lei Orçamentária $n^{\circ}$. 3.454, de 6 de janeiro de 1918. Sobre a ação indigenista do General Rondon e sua participação no SPI, ver seu livro Rumo ao oeste: conferência realizada pelo general Rondon no D.I.P. em 30-IX-40 e discursos do Dr. Ivan Lins e do general Rondon, pronunciados na Associação Brasileira de Educação. Rio de Janeiro: Biblioteca Militar, 1942. 
O SPILTN estruturou-se com uma Diretoria Geral instalada na capital federal no Rio de Janeiro, e 13 Inspetorias Regionais em diversos Estados da federação, e ainda previa as Povoações Indígenas e os Centros Agrícolas espalhados pelo Brasil. ${ }^{6}$

No Paraná, foi criada a $7^{\mathrm{a}}$ Inspetoria Regional, instalada no dia $1^{\circ}$ de outubro de 1910. Com um crédito concedido de $3.000 \$ 000$ (três contos de réis), o seu primeiro Inspetor foi o capitão de engenharia José Ozório. ${ }^{7}$ Ele alugou a casa do Sr. Manuel de Macedo, situada na Rua $1^{\circ}$ de Março n. 2, no centro de Curitiba, e ali iniciou as atividades do SPILTN no Paraná. Comprou móveis e utensílios diversos, material de escritório, e contratou o Sr. Tibúrcio dos Santos Ribeiro como escrevente para registrar a movimentação da $7^{\mathrm{a}}$ Inspetoria. ${ }^{8}$

Depois de instalado, o capitão José Ozório e seu escrevente prepararam a inauguração do novo órgão federal na capital do Paraná, realizada no dia 19 de novembro de 1910. Ele convidou o governador do Estado, o Sr. Francisco Xavier da Silva, as autoridades militares da região, secretários de Estado e outras pessoas importantes da política local, além das patentes militares sediadas em Curitiba. A cerimônia foi modesta como conta o capitão José Ozório: "Explicado por mim, em breve allocução, o motivo do convite, foi em seguida içada a bandeira; após a cerimônia, offerecemos aos convidados um copo dagua, sendo então pronunciadas varias saudações enthusiasticas." (OZÓRIO, 1910: 2)

A cerimônia pode ter sido modesta no buffet servido, mas com certeza não houve modéstia nos discursos ali pronunciados. O Sr. Governador do Estado do Paraná, Francisco Xavier da Silva, encerrou os pronunciamentos elogiando a ação do Ministério da Agricultura por ter criado o SPILTN para proteção dos povos indígenas. O discurso do governador Xavier da Silva foi reproduzido na sua mensagem ao Congresso Legislativo do Estado do Paraná, feita em fevereiro de 1911. Ele destacou a ação do ex-ministro da Agricultura Rodolfo

\footnotetext{
6 Há um grande debate sobre o papel do SPI, e são listados abaixo alguns textos que representam esse debate: Luiz Bueno Horta BARBOSA. O Serviço de Proteção aos Índios e a história da colonização do Brasil. Rio de Janeiro: Typografia do Jornal do Commercio, 1919. Arthur Martins FRANCO. Em defesa do índio e do sertanejo contra "O Serviço de Proteção aos Índios e Localização de Trabalhadores Nacionais" no Estado do Paraná. Curitiba: Cia. Editora O Estado do Paraná, 1925. Darcy RIBEIRO A política indigenista brasileira. Rio de Janeiro: Ministério da Agricultura-Serviço de Informação Agrícola, 1962. David Hall STAUFFER. Origem e fundação do Serviço de Proteção aos Índios. Trad. Jürgen Philipson. São Paulo. Revista de História, 37 a 44. 1959/1960. José Mauro GAGLIARDI. O indígena e a república. São Paulo: Hucitec, 1989. Para uma leitura crítica do SPI, ver os trabalhos de Antônio Carlos de Souza LIMA: O governo dos índios sob a gestão do SPI. In Manuela Carneiro da CUNHA (org.) História dos índios no Brasil. 2. ed. São Paulo: Companhia das Letras, 1998. Aos fetichistas, ordem e progresso: um estudo do campo indigenista no seu estado de formação. Dissertação de Mestrado apresentada ao PPGAS/MN-UFRJ. Rio de Janeiro: Museu Nacional, 1985. Uma síntese dessa dissertação foi publicada com o título de Sobre indigenismo, autoritarismo e nacionalidade. In Sociedades Indígenas \& Indigenismo no Brasil, organizado por João Pacheco de OLIVEIRA FILHO. Rio de Janeiro: Marco Zero, 1987. Ainda de ACS LIMA, ver a tese de doutorado Um grande cerco de paz: poder tutelar e indianidade no Brasil. Petrópolis: Vozes, 1995. Para o período de 1930 em diante, ver o trabalho de Leandro Mendes ROCHA. A política indigenista no Brasil: 1930-1967. Goiânia: Ed. UFG, 2003. 7 O capitão José Ozório era engenheiro militar, foi nomeado para o SPILTN no dia 27 de setembro de 1910 e tomou posse no dia $1^{\circ}$ de outubro de 1910, conforme o Livro para registro de títulos dos funcionários da Inspetoria de Proteção aos Índios e Localização dos Trabalhadores Nacionais no Estado do Paraná. SPILTN 7ª IR. Filme 80, fotograma 206.

$8 \mathrm{Um}$ dos livros que o escrevente Tibúrcio dos S. Ribeiro fez foi o da contabilidade da Inspetoria. Nele, estão descritos os créditos recebidos e a descrição das despesas efetuadas de outubro de 1910 a dezembro de 1912. SPILTN IR. Filme 80, fotogramas 0215-0277
} 
Miranda e frisou que no Paraná não se registravam atos de perseguição contra as populações indígenas:

Pode-se affirmar que no Estado não se registram actos de atrocidade ou perseguição contra os selvicolas, antes são recebidos em toda a parte com carinho e benevolência.

Este mesmo pensamento do Illustre ex-Ministro tem tido o poder legislativo do Estado, votando a lei 853 de 22 de Março de 1909 e o poder executivo fazendo baixar os decretos seguintes. (SILVA, 1911: 11)

E fez questão de citar os decretos estaduais que reservavam áreas de terras para os índios, que estão destacados no Quadro abaixo.

Quadro 1. Decretos do Governo do Paraná reservando terras às populações indígenas em várias partes do Estado.

\begin{tabular}{|c|c|c|}
\hline Decreto/Data & Descrição & Fonte \\
\hline $\begin{array}{c}\text { Decreto no } 6 \\
(5 / 7 / 1900)\end{array}$ & $\begin{array}{l}\text { Fixa as terras dos Kaingang dos aldeamentos de São } \\
\text { Jerônimo e São Pedro de Alcântara nas terras } \\
\text { devolutas "sitas entre os Rios Tibagi, Apucarana, } \\
\text { Apucaraninha e a serra do Apucarana no município do } \\
\text { Tibagy." }\end{array}$ & $\begin{array}{lll}\text { Estado do Paraná } & - \\
\text { Leis, } & \text { Decretos } & \text { e } \\
\text { Regulamentos de } 1900 .\end{array}$ \\
\hline $\begin{array}{c}\text { Decreto n } 6 \\
(31 / 7 / 1901)\end{array}$ & $\begin{array}{l}\text { Fixa as terras dos Kaingang do cacique Jembre em } \\
\text { Guarapuava. "Fica reservada para o estabelecimento da } \\
\text { tribu indígena de Coroados, ao mando do cacique } \\
\text { Jembre, e a outras tribus que quizerem alli se } \\
\text { estabelecer, uma area de terras comprehendida nos } \\
\text { limites seguintes: A este o Rio das Cobras. A oeste o Rio } \\
\text { União. Ao sul a picada velha, que do Xagu vae a colônia } \\
\text { da Foz do Iguassu e ao norte a picada nova que } \\
\text { demanda a mesma colônia." }\end{array}$ & $\mid \begin{array}{lcc}\text { Estado do Paraná } & - \\
\text { Leis, } & \text { Decreto } & \text { e } \\
\text { Regulamentos de } 1901 .\end{array}$ \\
\hline $\begin{array}{l}\text { Decreto } n^{0} \\
(9 / 9 / 1901)\end{array}$ & $\begin{array}{l}\text { Fixa as terras dos Kaingang chefiados pelos caciques } \\
\text { Paulino Arak-xo e Pedro Santos nas margens do Rio } \\
\text { Ivaí, entre os Rios do Peixe ou Ubasinho e o Ribeirão } \\
\text { do Jacaré e o cume da Serra da Apucarana no } \\
\text { município de Guarapuava. }\end{array}$ & $\mid \begin{array}{lcc}\text { Estado } & \text { do } \text { Paraná } & - \\
\text { Leis, } & \text { Decretos } \\
\text { Regulamentos de } 1901 .\end{array}$ \\
\hline $\begin{array}{l}\text { Decreto } n^{\circ} \\
(2 / 3 / 1903)\end{array}$ & $\begin{array}{l}\text { Fixa as terras dos Kaingang do cacique Antonio } \\
\text { Joaquim Cretã, de Palmas. "Fica reservada para o } \\
\text { estabelecimento de tribus indígenas as terras } \\
\text { occupadas pelas cabidas do cacique Cretã, com as } \\
\text { seguintes divisas: a partir da cabeceira do Ribeirão do } \\
\text { Lageado Grande a cabeceira do Ribeirão Palmeirinha, } \\
\text { e por estes dous rios abaixo ate o Iguassu que será } \\
\text { divisa norte, respeitado os direitos de terceiros." }\end{array}$ & $\mid \begin{array}{lcc}\text { Estado do Paraná } & - \\
\text { Leis, } & \text { Decretos } & \text { e } \\
\text { Regulamentos de 1903. }\end{array}$ \\
\hline
\end{tabular}

As demarcações enunciadas no discurso de inauguração da Regional do SPILTN no Paraná e também presentes na mensagem de governo aos deputados estaduais, no início da 
Legislatura de 1911, eram do interesse das elites locais, pois, ao fixar onde os indígenas deveriam permanecer, eles também definiam onde não podiam. Isso liberava terras para serem negociadas. As elites vislumbravam não apenas os valores das terras, mas calculavam nelas os valores das imensas reservas de madeira que propiciariam bons lucros aos seus proprietários.

\section{A primeira viagem do SPILTN aos aldeamentos indígenas no vale do Rio Tibagi}

De volta às lides da recém-criada $7^{\mathrm{a}}$ Inspetoria Regional do SPILTN no Paraná, o capitão Jose Ozório tomou todas as medidas para a realização de uma expedição de inspeção ao vale do Rio Tibagi, onde se concentravam uma grande parcela da população indígena no Paraná. A Inspetoria teve o cuidado de solicitar um crédito de $4.000 \$ 000$ (quatro contos de réis) para compra de brindes a serem oferecidos aos índios que seriam visitados, e créditos de $8.000 \$ 000$ (oito contos de réis) para custear os gastos da expedição. ${ }^{9}$

Uma semana depois, em 25 de novembro, o capitão Ozório e comitiva partia para os "sertões"10 do norte do Estado. Seu destino era os Toldos indígenas ${ }^{11}$ que existiam no vale do Rio Tibagi. Ele disse que queria conhecer os "selvagens na própria cabana", (OZÓRIO, 1910: 2) no seu estado de pobreza, só assim ele poderia traçar os rumos da missão da $7^{\mathrm{a}}$ Inspetoria.

O inspetor seguiu embarcado de trem para a cidade de Castro onde encontrou o restante da comitiva. Depois de dois dias de preparativos em Castro, a comitiva completa prosseguiu para a vila de Tibagi na qual chegaram no dia 29 de novembro de 1910. Ali procurou o coronel Telêmaco Morocines Borba, experiente sertanista. O encontro com o Cel. Telêmaco ocorreu com respeitabilidade e austeridade, conforme as palavras do capitão Ozório: "Recebeu-nos o respeitável e experiente concidadão, com lhaneza e sinceridade que o caracterisam e distinguem." (OZÓRIO, 1910: 2)

O Cel. Telêmaco Borba, nessa época em 1910, estava com 70 anos e morava na cidade de Tibagi. Tinha uma vasta experiência com os índios Kaingang, Guarani e Kayowá do vale do

\footnotetext{
9 As despesas da expedição e dos brindes distribuídos aos índios estão registradas no Livro de Despezas da $7^{\mathrm{a}}$ Inspetoria Regional. SPILTN IR. Filme 80, fotogramas 218-220.

10 É utilizada aqui a palavra sertão, que aparece nos documentos da época com reservas. Para os agentes do Estado, ela tem o significado de lugares desabitados ou com pouca densidade demográfica, lugares perigosos, lugares a serem conquistados, civilizados, etc. Mas para as populações indígenas, esses lugares são conhecidos, são os ambientes onde nasceram, onde vivem e serão enterrados. São os lugares onde viveram os seus antepassados, os animais e plantas que manejam e os espíritos que os protegem.

11 Era como se nominava na época os locais de moradias dos índios. Para maiores detalhes sobre as nomenclaturas desses locais, ver Lúcio Tadeu MOTA, Aldeamento. In Arquivo Público do Paraná (org.) Catálogo seletivo de documentos referentes aos indígenas no Paraná provincial: 1871-1892. Curitiba: Imprensa Oficial, 2009, v. 4, p. 15-18.
} 
Tibagi. $^{12}$ Além de todas suas atividades administrativas e experiências no trato com os índios, em 1910 ele já tinha publicado suas obras sobre as populações indígenas com quem havia convivido. ${ }^{13}$

Portanto, o capitão José Ozório estava certo de fazer uma parada na vila de Tibagi e consultar o velho sertanista. Este lhe informou detalhes dos vales dos Rios Tibagi e Paranapanema. Com certeza colocou-os a par das antigas Colônias Indígenas de São Jerônimo e São Pedro de Alcântara, da Colônia Militar do Jataí e sobre as antigas Reduções Jesuíticas de Santo Inácio e Loreto no Rio Paranapanema, locais até onde podiam ir com certa segurança.

Depois dessa conversa com Telêmaco, partiram de Tibagi no dia 31 de novembro e chegaram à longínqua povoação de São Jerônimo no dia 3 de dezembro. Mas as notícias colhidas na vila sobre a insalubridade e as doenças que grassavam nos vales desses rios eram desalentadoras, tanto que foram ministrando medicamentos contra a maleita a inúmeros enfermos que foram encontrando ao longo da picada para São Jerônimo. ${ }^{14} \mathrm{~A}$ comitiva era composta, além dos cavaleiros, de 10 mulas carregadas de alimentos e brindes para os índios.

A povoação de São Jerônimo estava em festa com a visita pastoral que o vigário de Tibagi ali fazia, mas mesmo assim a notícia da chegada da comitiva do SPILTN fez com que as atenções da população local - nacionais e indígenas - se voltassem para o capitão Ozório e seus homens. Todos acreditavam que a chegada da comitiva era devido aos ataques que um

12 A biografia de Telêmaco consta que ele chegou em 1865 na região onde foi administrador do Aldeamento Indígena de São Jerônimo. Outros membros da sua família já estavam na região há mais tempo. Seu irmão Joscelin Borba administrava o Aldeamento do Paranapanema, dos índios Kayowá, desde 1862, e seu pai era o diretor da Colônia Militar do Jataí desde 1863. Telêmaco ocupou, de 1865 a 1904, vários cargos nos órgãos de governo instalados na região. Foi suplente de delegado e inspetor escolar na Colônia Militar do Jataí; foi Diretor do Aldeamento Indígena de Barreiros em 1878 e Diretor dos Índios no Tibagi em 1880. Percorreu os Rios Tibagi, Paranapanema e Piquiri com seu irmão Nestor Borba em 1876, entrando em contato com vários grupos indígenas espalhados ao longo desses rios, e também viajou com o engenheiro inglês Thomas Bigg-Wither pelo Rio Tibagi em 1873. A partir dos anos de 1880, ele se fixou na cidade de Tibagi onde foi vereador, prefeito, capitão e coronel da Guarda Nacional e deputado estadual por várias legislaturas.

13 Sobre os índios Kaingang, Guarani (Nandewá) e os Caiuás (Kayowá), Telêmaco Borba escreveu: Breve notícia sobre os índios Caingangs, conhecidos vulgarmente por Coroados e que habitam no território da Província do Paraná. In Sebastião PARANÁ. Chorographia do Paraná. Curitiba: Livraria Econômica, 1899. Observações sobre os indígenas do Estado do Paraná. Revista do Museu Paulista, v. 6. São Paulo, 1904. Actualidade indigena. Curitiba: Impressora Paranaense, 1908. Pequeno Vocabulário das Línguas Portuguesa e Caingangs ou Coroados. In Almanach do Paraná, 1903, p. 201-205. Sobre a vida de Telêmaco Borba, escreveu Arthur Martins FRANCO O Coronel Telêmaco Morosini Borba. Curitiba. Arquivos do Museu Paranaense, vol I, 1941. Túlio VARGAS. O Indomavel Republicano. Curitiba. O Formigueiro, 1970, e do mesmo autor, O Maragato - a vida lendária de Telêmaco Borba, Curitiba: Jurua, 2001. Telêmaco morreu da gripe espanhola em 1918.

14 Na sua mensagem para a Assembleia Legislativa em fevereiro de 1911, o Presidente do Estado Sr. Francisco Xavier da Silva informou que nos anos de 1909 e 1910 tinha manifestado "casos de escarlatina, na Capital e na cidade de Ponta Grossa, e de varicella em quase todos os Municípios do Estado." e que as autoridades sanitárias do estado tinham desenvolvidos todos os esforços para combater essas doenças. A variedade e a constância dessas doenças em todos os relatórios oficiais, bem como o impacto delas nas populações indígenas merecem estudos específicos e mais aprofundados que não caberiam neste texto. Cf. Mensagem ao Congresso Legislativo do Estado do Paraná pelo Dr. Francisco Xavier da Silva, Presidente do Estado ao instalar-se a $2^{\mathrm{a}}$ sessão da $10^{\mathrm{a}}$ Legislatura em $1^{\circ}$ de Fevereiro de 1911. Curityba. Typografia d'A Republica, 1911, p. 6. 
grupo de Kaingang do vale do Rio Laranjinha tinha recém-feito aos nacionais que teimavam em ocupar seus territórios entre os Rios Congonhas e Cinzas.

Ali em São Jerônimo o capitão José Ozório soube das notícias dos conflitos que assolavam a região entre os Rios Congonhas e Cinzas. Soube que "os coroados bravios", os Kaingang, tinham ferido uma senhora e flechado um menino. A população cabocla de São Jerônimo e adjacências estava impaciente e alarmada, muitos tinham abandonado suas propriedades com os "paióis cheios de cereais". A presença da comitiva do SPILTN encorajou a população local que sugeriu "planos de pacificação" dos índios. Planos que foram considerados "sinistros" (OZÓRIO, 1910: 4) pelo capitão Ozório, que logo os desencorajou pedindo prudência ${ }^{15}$

Depois de dois dias de chuvas intensas que deixou a comitiva retida na povoação, ela partiu para as aldeias espalhadas ao longo do Rio Tibagi. O objetivo do capitão Ozório era visitar todas as aldeias indígenas existentes naquela região do Tibagi. Feitos os preparativos para a viagem, arriados os cavalos e éguas, carregadas as mulas, contratados os guias, partiram rumo aos toldos dos Kaingang na Serra da Apucarana. Desceram as encostas do vale e atravessaram o Rio Tibagi na barra do Rio Apucarana, subiram novamente a encosta da margem esquerda e avistaram as primeiras cabanas dos Kaingang.

\section{$\checkmark \quad e m \tilde{a}^{16}$ da Boa Vista da Apucarana do cacique Ignácio Chocanban}

Depois de caminharem por volta de $20 \mathrm{~km}$, tinham chegado ao emã do cacique Ignácio Xokanban ${ }^{17}$ conhecida como aldeia Boa Vista da Apucarana, localizada no alto da serra do mesmo nome. Ali foram recebidos com alegria por 114 pessoas que lhes serviram batatas cozidas num rancho construído para recepção da expedição.

A população Kaingang da aldeia Boa Vista estava sofrendo com muitos casos de varicela e coqueluche. O capitão Ozório presenciou o funeral de uma criança morta de coqueluche e

\footnotetext{
15 Em São Jerônimo, os membros da expedição fizeram um levantamento do que tinha restado do antigo aldeamento fundado pelo Império em 1859. Havia uma casa arruinada coberta com telhas de barro, forrada e assoalhada. Em seu interior, ainda havia armários, camas, bancos, mesas e cadeiras de madeira. Os equipamentos para o fabrico de aguardente e melado de cana-de-açúcar ainda estavam ali armazenados: eram quatro tachos de cobre e dois alambiques. O sino da capela estava junto com 10 livros dos arquivos. Era o que tinha sobrado do aldeamento criado em 1859 por Joaquim Francisco Lopes e dirigido por muitos anos pelo Frei Luis de Cimitille até sua saída em 1881. Com a saída do Frei Cimitille, o aldeamento começou a entrar em decadência e parou de funcionar em 1900, quando o governo do Paraná extinguiu as verbas destinadas a ele.

16 Emã é a denominação Kaingang para aldeia. É utilizada aqui a definição encontrada no Dicionário do frei Mansueto Barcatta de Val Floriana, que diz ter aprendido a língua Kaingang no Tibagi. Cf. Diccionarios Kainjgang-Portuguez e Portuguez-Kainjgang composto pro Frei Mansueto Barcatta de Val Floriana da ordem dos missionários capuchinhos do Estado de São Paulo. Revista do Museu Paulista, Tomo XII, São Paulo, Typ. do Diário Official, 1920.

17 Daqui em diante colocaremos as palavras e os nomes indígenas em itálico e escrito conforme a Convenção da Associação Brasileira de Antropologia sobre a grafia de nomes tribais. Revista de Antropologia, n. 2, v.2, p. 150-152, 1954.
} 
ficou impressionado com o ritual de sepultamento realizado por um Kuia ${ }^{18}$. Este levava uma "grande canna, que era o alimento para a intérmina viagem, a qual, seria dentro em pouco sepultada com o cadáver" (OZÓRIO, 1910: 4).

No final da tarde, retornaram para a margem do Rio Tibagi onde pernoitaram num rancho feito pelos índios. Pela descrição do capitão Ozório: um rancho de folhas de palmeira de um só "panno que ia ter ao chão" (OZÓRIO, 1910: 4), era um típico wãre Kaingang. Os wãre ${ }^{19}$ eram abrigos temporários que os Kaingang faziam quando estavam em expedições de caça nos pinheirais, nos saleiros naturais ou acampados nas margens dos rios pescando, ou simples abrigo para passar uma noite quando estavam em deslocamento.

\section{$\checkmark$ emã da barra do Apucaraninha do cacique Kaingang Chico Telêmaco}

Na manhã do dia seguinte, 7 de dezembro de 1910, desceram o Rio Tibagi até a barra do Rio Apucaraninha. Ali, na sua margem esquerda, estava o toldo do cacique Chico Telêmaco. Era um emã pequeno se comparado com o de Boa Vista. Ali morava a parentela do cacique Chico constituída de 21 pessoas. Nesse local, também grassavam as febres que atingiam todo o médio Rio Tibagi nesse verão de 1910. O capitão Ozório informou que o grupo do cacique Chico Telêmaco estava em terras particulares pertencentes à fazenda Três Bocas. De acordo com o Decreto $n^{\circ} 6$, de 5 de julho de 1900, o limite norte das terras reservadas aos índios era o Rio Apucaraninha.

Entre os dias 6 e 7 de dezembro de 1910, o capitão José Ozório visitou dois emãs (Toldos ou Aldeamentos) Kaingang na margem esquerda do médio Tibagi: o primeiro, Boa Vista do Apucarana, estava no cimo da Serra da Apucarana e as moradias do cacique Ignácio Xokanban estavam dentro dos limites fixados pelo Decreto $\mathrm{n}^{\circ}$ 6; já as moradias do cacique Chico Telêmaco estava fora dos limites do referido decreto.

Os territórios onde o cacique Chico Telêmaco estava com seu grupo em 1910 já tinham sido titulados a particulares e pertenciam à Fazenda Três Bocas. Era o processo de desterritorialização dos Kaingang na margem esquerda do Rio Tibagi em andamento.

No período imperial, a tentativa de nucleamento dos grupos indígenas se dava através dos aldeamentos, isto é, procurava atrair os indígenas para os aldeamentos e proximidades para catequizá-los e civilizá-los, transformando-os em população agricultora nacional. Mas não havia a obrigatoriedade de conter os grupos em áreas demarcadas. Tanto que os diversos grupos familiares Kaingang, Kayowá e Guarani circulavam por todo o vale e serras

18 o kuiã é uma pessoa especial entre os Kaingang, ele é o responsável pela ligação dos homens com o sobrenatural, pela mediação dos homens com a natureza, tem capacidade de cura, guarda conhecimentos antigos e é capaz de prever acontecimentos. Sobre os impactos das doenças nas populações indígenas.

19 No Dicionário do Frei Mansueto Barcatta de VAL FLORIANA encontra-se a expressão va'́re, para definir pouso. 
da região, com emãs/tekoha estáveis em locais de maior abundância e os wãre em locais de coleta, caça e pesca sazonais.

Os indígenas tinham uma política de utilização dos aldeamentos do Império muito bem definida. Para eles, os aldeamentos serviam como locais onde poderiam acessar bens materiais da sociedade envolvente, locais de abrigo para refugiarem-se de perseguições de grupos inimigos ou de bugreiros e locais de abastecimento de alimentos nas roças cultivadas com recursos do governo. Eles utilizavam dos aldeamentos, mas não estavam confinados, restritos a viverem nos limites do aldeamento. $\mathrm{Na}$ nova conjuntura da República, isso iria mudar.

A Constituição de 1891 definiu que as terras não tituladas, consideradas devolutas, passariam a pertencer aos Estados da federação. Como os territórios indígenas, com raras exceções, não tinham títulos, eles foram considerados como devolutos e prontos a serem negociados, cedidos, permutados, conforme os interesses dos governantes e das elites regionais. Muito mais buscando definir quais terras eram devolutas e poderiam ser negociadas, do que quais eram as terras indígenas, o Estado do Paraná passou a reservar áreas específicas para os índios com os decretos do início do século XX. Assim, reservar áreas de terras para os índios era dizer que eles não tinham mais a liberdade de manejar todos seus territórios como vinham fazendo até então.

No caso dos grupos que viviam na margem esquerda do Tibagi, o Decreto $n^{\circ} 6$ de 1901 estava lhes dizendo que daí em diante eles só podiam ter seus emãs e wãre entre os limites do decreto. Mas o cacique Chico Telêmaco e seu grupo, passados dez anos, teimavam em não obedecer ao Decreto $\mathrm{n}^{\circ} 6$ e continuavam com sua aldeia fora dos limites por ele estabelecido. Essa era uma das estratégias utilizadas pelos Kaingang na defesa dos seus territórios ancestrais.

\section{$\checkmark$ emã do cacique Siqueira na barra do Rio do Tigre no Rio Tibagi}

A viagem da expedição da $7^{\text {a }}$ Inspetoria Regional do Paraná prosseguiu Rio Tibagi abaixo. No dia 8 de dezembro, eles chegaram no emã do cacique Siqueira, na barra do Rio do Tigre no Tibagi. Ali, o cacique Siqueira vivia "patriarchalmente com sua família composta de 18 pessoas" (OZÓRIO, 1910: 5). O "Capitão Siqueira", como foi chamado pelos homens da expedição, era casado com três mulheres umas das quais tinha recém-falecido, e a causa do óbito novamente foi debitada na insalubridade do Tibagi naquele verão de 1910.

Era mais um grupo familiar Kaingang com seu emã na confluência de um rio menor no Tibagi, vivendo conforme seus antigos costumes apesar de mais de cinquenta anos da presença dos padres capuchinhos nas Colônias Indígenas de São Pedro de Alcântara e São 
Jerônimo aconselhando-os a deixar o costume antigo de ter mais de uma esposa e adotar a monogamia.

\title{
$\checkmark$ emã da Limeira do cacique Julio Feio no alto da Serra de São Jerônimo
}

Ainda no dia 8, a expedição subiu os contrafortes do Tibagi em direção aos planaltos onde situava um dos quatro emãs das vizinhanças da povoação de São Jerônimo. No emã da Limeira, comandado pelo cacique Julio Feio, eles foram recebidos com tiros e toques de buzina, antigo costume Kaingang de avisar o povo quando da chegada de visitas. A casa do já velho cacique Julio era circundada por inúmeras choças de folhas de palmeiras que abrigavam as famílias das 118 pessoas que ali viviam. A avaliação do capitão Ozório sobre o emã da Limeira é diferente das que tinha visitado nas margens do Tibagi.

\begin{abstract}
A aldeia da Limeira, é de todas as 4 que ficão na circunvizinhança do povoado de S. Jeronimo, a melhor situada.

Acha-se no esplendido planalto de S. Jeronimo, a 920 metros acima do nível do mar, seu clima é ameno, tem magníficos campos para criação e excellentes terras para cultura. (OZÓRIO, 1910: 5)
\end{abstract}

O grupo Kaingang comandado pelo cacique Julio tinha características diferentes dos dois anteriores. Ele era parecido com o grupo do cacique Ignácio Xokanban da Boa Vista da Apucarana. Ambos estavam no alto da serra a certa distância do rio, o primeiro na margem esquerda do Tibagi e o outro na margem direita. Entre eles estavam grupos familiares menores assentados nas embocaduras dos Rios Apucaraninha e Tigre, afluentes do Tibagi. ${ }^{20}$

Tanto a aldeia do cacique Siqueira na barra do Rio do Tigre no Rio Tibagi como o da Limeira do cacique Julio Feio no alto da Serra de São Jerônimo estavam nos limites da fazenda São Jerônimo asseverou o capitão Ozório. É o que se verá mais adiante.

Encerrada a visita, a expedição do SPI voltou para a povoação de São Jerônimo no dia 9 de dezembro. Ali permaneceram por alguns dias recebendo a visita dos índios que viviam na região, inclusive os visitados por eles nos últimos dias. Os indígenas chegaram a São Jerônimo "marchando garbosamente (...) como desfile marcial" (OZÓRIO, 1910: 6). Foram a convite do capitão Ozório para receber os brindes por ele prometido, quais sejam: instrumentos agrários, roupas, espingardas, anzóis, etc. O capitão Ozório ressalva que "os índios estavam desconfiados, e não queriam acreditar que os brindes que lhes levávamos e as muitas promessas de proteção, não fossem do Governo Velho (monarchia) de que viviam

20 Essa configuração espacial parece estar obedecendo a uma lógica de ocupação do território que não caberia discutir aqui porque implica em informações arqueológicas e ambientais da região. 
saudosos." (OZÓRIO, 1910: 6) Havia o descrédito dos índios no novo regime republicano, pois, desde o fim do Império, há mais de 20 anos, não tinham recebido em seus emãs a visita de autoridades e nem recebido presentes e promessas de proteção, ao contrário, os aldeamentos tinham sido desativados e as verbas tinham sido cortadas.

Após a distribuição dos brindes, parte da tropa retornou à cidade de Tibagi para buscar os brindes restantes. Enquanto aguardava seu retorno, o chefe da expedição resolveu visitar os toldos indígenas que existiam nos arredores do antigo aldeamento de São Pedro de Alcântara no Jataí. ${ }^{21}$ O que foi feito entre os dias 11 e 14 de dezembro de 1910, antes de seguir sua viagem para o sul.

\section{$\checkmark$ Os emãs e os tekoha² do Jataí}

De São Jerônimo ao Jataí foi uma viagem de $75 \mathrm{~km}$ feita em um dia e meio pela antiga picada coberta de majestosas árvores que protegia os viajantes do sol abrasante de dezembro. Chegaram à sede da extinta Colônia Militar do Jataí na manhã do dia 12 de dezembro, onde já os esperavam os caciques e lideranças dos indígenas da região.

No Jataí, o chefe do SPILTN do Paraná teria que conversar com "3 nações distinctas: coroados, guaranys e cayouás" (OZÓRIO, 1910: 7). Os Coroados eram como se nominavam na época os Kaingang; os Guarani eram os da parcialidade Ñandewa que chegaram à região após a Guerra do Paraguai, e os Kayowá, também uma parcialidade Guarani, estavam no Jataí desde os primeiros anos de fundação da Colônia Militar no início dos anos de 1850.

Com a desativação do Aldeamento Indígena de São Pedro de Alcântara, no final do século XIX, após a morte do seu diretor Frei Timóteo de Castelnuovo em 1895, os grupos indígenas que nele viviam reagruparam-se em novos aldeamentos, conforme a descrição do capitão Ozório. Eram eles: Engenho de Ferro, Poço Bonito, Limoeiro e Tirajuba (ou Tirafuba).

Estavam todos eles nas margens do Tibagi. Nos três primeiros emãs, viviam 111 índios Kaingang, e no tekoha de Tirafubá viviam misturados os Guarani Ñandewá e os Guarani Kayowá num total de 104 pessoas. Todos eles eram os remanescentes do antigo aldeamento

21 Para maiores detalhes sobre o aldeamento de São Pedro de Alcântara, ver Lúcio T. MOTA. As colônias indígenas no Paraná provincial. Curitiba: Aos quatro ventos, 2000.

22 Tekoha é a denominação Guarani para seus locais de moradia. El tekoha es "el lugar en que vivimos según nuestras costumbres", es la comunidad semi-autónoma de los Paí. Su tamaño puede variar en superficie (...) en la cantidad de familias (de 8 a 120 en los casos extremos), pero estructura e función se mantiene igual. In B. MELIÁ; G. GRUNBERG; F. GRUNBERG. Etnografia Guarani del Paraguay contemporaneo: los Paí-Tavyterã. Suplemento Antropológico Universidad Católica. Asunción, v. 11, n. 1-2, p. 218, 1976. De agora em diante, será utilizada essa denominação para nominar os locais de moradia dos Guarani-Kayová ou Ñandeva que eram independentes dos aldeamentos oficiais. Conforme Pasquale PETRONE, aldeia é termo trazido pelo colono português que aqui se instalou. Na área de origem tem um significado preciso. Vê-se utilizado para indicar uma forma particular de hábitat rural concentrado; corresponde ao villaggio italiano, village francês, dorf alemão. Na nova terra passou a ser utilizado para indicar as tabas indígenas (...). Aldeamentos Paulistas. São Paulo: Edusp, 1995, p. 103. 
imperial de São Pedro de Alcântara situado na margem esquerda do Rio Tibagi em frente à Colônia Militar do Jataí.

Como já havia anotado para os aldeamentos das margens do Tibagi mais ao sul, o capitão Ozório reafirmou o flagelo das febres palustres que atacava as populações no Jataí.

Lá encontramos em Dezembro numerosos casos não só de maleita, como de varicella que há dois anos grassa intensamente em todo o estado.

A população dessas paragens é rachitica e pallida, devido, talvez, á endemia das febres e ao excessivo calor, que atinge a $38^{\circ}$ centigrados a sombra. (OZÓRIO, 1910: 7)

Apesar de piscoso e rico em diamantes, o Rio Tibagi tinha o problema das febres ${ }^{23}$ que atacava os que teimavam em viver nas suas proximidades. A impressão do capitão Ozório era de que a vida naqueles sertões era muito difícil, e tinha-se agravado nos últimos anos com os cortes das verbas para o aldeamento de São Pedro de Alcântara, e dos recursos da Colônia Militar do Jataí que tinha se emancipado.

A nossa visita á sede do antigo aldeiamento de S. Pedro de Alcantara produziu-nos tristissima impressão, pelo estado ruinoso em que esta. A igrejinha está se desmoronando, a casaria abandonada esboroa-se e, por toda a parte, o mesmo aspecto desolador de ruína e decadência. (OZÓRIO, 1910: 7)

Nesses cinco dias que permaneceu no Jataí, ele testemunhou que os Guarani e os Kaingang continuavam vivendo nas imediações da Colônia Militar em quatro aldeias. Tinham sobrevivido ao Império com sua política de catequese e civilização, frei Timóteo de Castelnuovo estava morto há quinze anos, a Colônia estava em ruínas ${ }^{24}$ e o projeto Imperial de aglutinar as populações indígenas sob o comando de religiosos capuchinhos terminado.

As lideranças Guarani, Kayowá e Kaingang, que comandavam a existência de mais de 200 pessoas nos arredores do Jataí, tinham recebido o recado que o capitão Ozório iria visitálos, reuniram se todos na sede da antiga Colônia Militar e prepararam-se para recebê-lo,

23 Como já foi dito em nota anterior, o governo do Estado tinha registrado epidemias por todo o Estado nos anos de 1909 e 1910. Aqui apenas destacamos o registro dessas epidemias pelo capitão Ozório e a reafirmação da necessidade de futuras pesquisas sobre o tema.

24 O aldeamento de São Pedro de Alcântara foi fundado pelo Frei Timóteo de Castelnuovo em 2 de agosto de 1855, durou até a morte do mesmo em 18/5/1895. Cf. Lúcio T. MOTA. As colônias indígenas no Paraná provincial. 1. ed. Curitiba: Aos quatro ventos, 2000. 
ouvi-lo e apresentar suas demandas. E com certeza uma delas foi a questão das terras que o capitão anotou no seu relatório.

Sobre as aldeias Engenho de Ferro e Poço Bonito foi informado que elas estavam "em terras concedidas aos índios em 1850 e registradas conforme a lei no 1 de 1893." (OZÓRIO, 1910: 11) E os Kaingang da aldeia Limoeiro estavam em terras devolutas, isto é, em terras fora dos limites dos Decretos do início do século.

Os Guarani e os Kayowá, da aldeia Tirafubá, lhes disseram que tinham sido "expulsos, por alguém que legitimou e medio suas terras" (OZÓRIO, 1910: 11). Era necessário verificar a exatidão dessas denúncias na documentação do Estado, apesar de ter sido confirmada por "velhos conhecedores" da questão. E os Guarani e Kayowá ainda lhes argumentaram que pelo fato de viverem em "terras particulares" não se entregão á lavoura". (OZÓRIO, 1910: 11) O recado dos indígenas para o representante da República era claro: para transformá-los em agricultores era necessário a demarcação de suas terras.

Impactado pelo estado de falência da mais próspera Colônia Indígena implementada pelo governo do Império no Paraná e com a situação de penúria da Colônia Militar do Jataí, mas com as denúncias de esbulho de suas terras e solicitações dos indígenas, o capitão Ozório e comitiva iniciaram a viagem de retorno para São Jerônimo no dia 16 de dezembro.

\section{$\checkmark \quad$ Emã do Lambari do cacique Candido}

Da povoação de São Jerônimo a comitiva iniciou o caminho de volta, mas antes teriam que visitar mais quatro aldeias. Depois de caminharem sete léguas $(35 \mathrm{~km})$ em direção à sudeste, chegaram ao emã Lambari. Nessa localidade, fizeram distribuição de brindes e o recenseamento da população. Ali encontraram 97 índios Kaingang comandados pelo cacique Candido. A descrição do capitão Ozório leva a inferir que essa antiga aldeia Kaingang estaria hoje onde se localiza o Bairro de Lambari no município de Sapopema, pois, a alguns quilômetros a oeste desse distrito, encontra-se a Fazenda Inhô-ó. Esse era o nome que os Kaingang davam aos campos situados nos altos dos contrafortes da margem direita do Rio Tibagi em homenagem ao cacique Inhô-ó. Esses campos foram avistados pela expedição de John Henrique Elliot e Joaquim Francisco Lopes, em 1846, quando trabalhavam para o Barão de Antonina. ${ }^{25}$ Mais tarde, ela foi apossada por Feliciano Nepomuceno Prates que tinha

25 João da Silva Machado - Barão de Antonina - nasceu em Taquari, no Rio Grande do Sul, em 17/6/1872. Aos 18 anos de idade fez sua primeira viagem para Sorocaba tangendo tropas para comercializar e fixou-se nas margens da estrada para o sul nos campos da Faxina, nas proximidades de Itararé, em São Paulo. A partir de 1820 passou a figurar na política paulista enquanto continuava suas atividades comerciais de vender animais em Sorocaba, a empreitar a construção de estradas na província e, no início dos anos de 1840, iniciou as explorações e apropriações de imensos territórios indígenas no Paraná e Mato Grosso. A partir de 1853, com a independência da província paranaense, ele se tornou senador pela mesma e passou a viver na capital paulista, onde morreu em 28 de março de 1875 . Foi um dos homens mais poderosos e influentes do Império. Para maiores detalhes da sua biografia, ver Francisco de Barros BROTERO. Barão de Antonina. Apontamentos genealógicos. São Paulo, Escolas Profissionais Salesianas, s/d. Aluísio de ALMEIDA. Achêgas à 
aberto para o governo Imperial a estrada de Castro até a Colônia Militar do Jataí nos anos de 1850 .

Repetia aqui o padrão populacional dos outros dois emãs Kaingang: Boa Vista da Apucarana com 118 pessoas, o da Limeira no alto da Serra de São Jerônimo com 114 pessoas e este com 97. Devido à pressa em seguir para a região do Rio Preto como seus superiores lhe tinham determinado, o capitão Ozório não fez nenhuma descrição do grupo do cacique Candido, a não ser a contagem das pessoas.

Esses territórios Kaingang da margem direita do médio Rio Tibagi estavam em parte nos limites da Fazenda São Jerônimo doada pelo Barão de Antonina ao império para implementação do Aldeamento do mesmo nome em 1859.

Antes de partirem para as visitas às aldeias em 6 de dezembro, o capitão Ozório tinha solicitado ao escrivão do Cartório de São Jerônimo, o Sr. João Henrique Elliot, que verificasse em seus livros se havia algum registro de doação das terras da fazenda aos índios pelo Barão de Antonina. Elliot encontrou o registro de doação e fez uma cópia a pedido do capitão José Ozório que a levou para Curitiba. Pelo registro, o inspetor tomou conhecimento que a fazenda doada pelo Barão de Antonina ao governo do Império era de seis léguas quadradas, equivalente a 176.400 hectares. $^{26}$

Muito tempo depois, em julho de 1944, o Sr. Deocleciano de Souza Nenê, então inspetor especial do SPI, encontrou o documento em meio aos papéis da $7^{\text {a }}$ Inspetoria Regional, dele fez uma cópia que foi para o arquivo do Museu do Índio e do qual reproduzimos abaixo devido a sua importância.

biografia do Barão de Antonina. Revista do Arquivo Municipal de São Paulo, CXI v., 1947. p. 7-39. Especificamente sobre suas explorações no Paraná e Mato Grosso, ver o artigo de Maria C. C. WISSENBACH. Desbravamento e catequese na constituição da nacionalidade brasileira: as expedições do Barão de Antonina no Brasil meridional. Revista Brasileira de História, São Paulo, n. 15, v. 30, p. 137-155, 1995.

260 documento de "doação" das terras da Fazenda Inho-ó pelo Barão de Antonina ao Governo do Império está nos arquivos do Museu do Índio. Cf. SPILTN IR. Filme 75, fotograma 2.035. E esse João Henrique Elliot, que fez a cópia do documento para o Capitão Ozório, era filho de John Henry Elliot que junto com Joaquim Francisco Lopes tinham devassados todos territórios do Tibagi a serviço do Barão de Antonina desde 1840. 


\section{Prot eqge. \\ Tof H, Elliott, fls 1 ,}

João Henrique Elliott escrivão Intirino do Juizo

Districtal e Tabelião na fórma da le1, \& \& locallzacro de tro de terr dicas nacionaes, nina pars a concedidas a 0 Governo Imneriale elles encontre1 o regis nina para a localizaça de Indios Reg1stre-se, São Jeronymo 7 de outoados, o qual é do theor segutnto pertencente a o Aldeant de Outubro de 1895, P, Souza, Terreguinte. to são B1tuados 26 lo ca Colonis 1 litar leguas $N, N, O$ da Cidade de Catro ra, tendo ra, tendo por limites, a 0 Norte o Rebelrão de Sáo Pedro de Alcantara balxo toma o nome de R, São Joronge da Lixigoana e que ma1s a sua fos no R, Tibagy o a barra do Rebe1rão des rurnes mesmo R, T1bagy, e por este asol até a as cabeceiras do Esperanca, a do que nela cordilho Rebeirão até dos do R, a Leste pelo Esrigão que desse de dos $R$, de São Jeronymo, até as vertene de aguas do $R$, das Congonhas Lixigoana:, Estes terrenos tem as vertentes do sobre dito Ribe1r ̃onhas f1c1o, composta de campos ta pelo menos 6 leguas quadradas de aupa mattas de cultura, nas frotiferes, muitos Reb homals as produçoes das zonss tempertas as plantas tendo Re tendo altura sufficiente pars serem, todos elles nas partes superfice Aposição deste Aldesmento si tud os campos da Fortalo a os viandantes mento de São Pedio huma lonte de apolo parg a Coloni to a de São Pedro de Alcantara, Era oque se a Colonia Militar e Aldeato a $11 \mathrm{~s},-1$ do $\mathrm{L}$, de lancamento Je de Miranda Mathilde, \& São Jeronyerritorial, O Director, João F'erreira Era o que se sa Jeronymo 5 de Outubro de 1895.

elmente extrahi para aqui e me renorto regisiro de terras que bem e fi-

rique Elliott que o escrevi, me renorto em meu Cartorio e dou fé, Eu Hen

g. inal e dou fé,. São Jeronymo 16 de Dezeembro de 1910 O Escrivão, João Henrique Elliott

Confére com o original.

Curitiba, 4 de Julho de 1944.

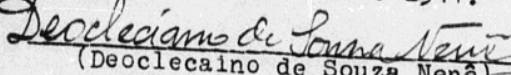

Deoclecaino de Souza Nenê

Inspetor Esp. do S.P.I.

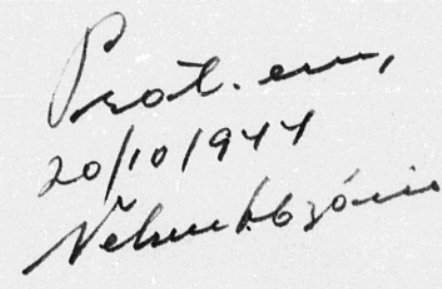

O Barão de Antonina fez uma operação singular no caso dessa fazenda. Nos idos dos anos de 1840 ele apropriou-se desses territórios Kaingang e em seguida, em 1859, num gesto de "altruísmo", doou parte deles ao Império para que Dom Pedro II implantasse ali um 
aldeamento para os Kaingang nos moldes do que tinha sido implantado no Jataí para os Kayowá em $1855 .{ }^{27}$

Mas diferente do aldeamento de São Pedro de Alcântara no Jataí, que não tinha limites definidos, a Fazenda São Jerônimo tinha certa exatidão na definição de seus limites. Parece indubitável que o Barão, ao doar esses terrenos, quis garantir um quinhão mais valioso, mais apropriado, para seus negócios de criação de gado que eram os territórios do cacique Inhô-ó.

Assim, ao mesmo tempo que atendia a política imperial de catequese e civilização dos índios com implantação de mais uma Colônia Indígena - a de São Jerônimo -, o Barão sinalizava para os Kaingang que a partir da implantação da Colônia eles tinham que ficar restritos nos limites da fazenda. Não podiam mais montar seus emãs e wãre, para coletar, caçar e pescar além dos rios e serras definidos na doação. Mas a realidade é mais complexa do que se planeja, e o processo histórico de São Jerônimo tomou rumos imponderáveis. Nem os brancos nem os índios respeitaram os limites da fazenda: os primeiros para não entrarem na área reservada aos índios, e os segundos para não saírem da área demarcada para eles.

A Colônia Indígena de São Jerônimo atraiu para a região contingente de populações não indígenas pobres que viviam nas franjas das grandes fazendas dos Campos Gerais, e ali começaram a demandar parcelas de terras no interior da fazenda doada aos índios. Os Kaingang não levaram ao pé da letra a política do governo imperial de catequese e civilização. Não se limitaram a circular, caçar, coletar, pescar e plantar roças apenas nas terras definidas; continuaram com suas caçadas, suas coletas, suas pescarias e montaram seus emãs e wãre muito além dos limites da fazenda "doada" pelo Barão de Antonina. O caso do cacique Candido é um exemplo: ele estava com sua gente nas proximidades da fazenda Inhô-ó, algumas léguas adiante do Ribeirão dos Pilões, no limite sudeste da Fazenda São Jerônimo.

Mas a tentativa de desterritorialização dos Kaingang no Tibagi, via papel com definição de áreas restritas a serem ocupadas, estava dada já em 1859 com as ações do Barão de Antonina e do governo Imperial. Pode ter sido este o modelo que inspirou os governantes republicanos do Paraná a reservar novas áreas aos índios pelos decretos do início do século XX.

27 O Barão de Antonina tinha construído sua fortuna negociando gado do Rio Grande na feira de Sorocaba, como empreiteiro na construção e manutenção de estradas e na incorporação de grandes extensões de terras em SP, PR e MS em seus domínios. Todos os campos naturais existentes na margem direita do rio Tibagi, ao norte dos Campos Gerais tinham sido devassados por seus homens na década de 1840. Para maiores detalhes sobre as expedições de reconhecimento e ocupação desses campos a mando do Barão, ver: Lúcio T. MOTA. A guerra de conquista nos territórios dos índios Kaingang do Tibagi. Revista de História Regional, Ponta Grossa - PR, v. 2, n.1, p. 187-207, 1997. Lúcio T. MOTA. As populações indígenas Kaiowá, Kaingang e as populações brasileiras na bacia dos rios Paranapanema/Tibagi no século XIX: conquista e relações interculturais. Fronteiras (Campo Grande), v. 9, p. 47-72, 2007. Lúcio T. MOTA. Os índios Kaingang e seus territórios nos campos do Brasil meridional na metade do século passado. In: Lúcio Tadeu Mota; Francisco Silva Noelli; Kimiye Tommasino. (orgs.) Uri e Wãxi: estudos interdisciplinares dos Kaingang. $1^{\mathrm{a} e d .}$ Londrina: Eduel, 2000, v. 1, p. 81-190. 
Depois de distribuírem brindes aos Kaingang do cacique Candido, a expedição rumou para sudoeste, acompanhando o Rio Lambari até chegarem ao Rio Tibagi. Entre as encostas do Pico Agudo e o Salto Mauá, atravessaram o rio e estavam novamente na sua margem esquerda algumas dezenas de quilômetros mais ao sul dos emãs de São Jerônimo e da Serra da Apucarana.

\title{
$\checkmark$ emã do Salto Mauá do cacique Timotheo
}

Ao atravessarem o Rio Tibagi encontraram o grupo Kaingang chefiado pelo cacique Timotheo. Seu emã tinha sido assentado às margens do Tibagi na altura da foz do Ribeirão Mococa, onde é a atual Terra Indígena Mococa.

O cacique Timotheo tinha chegado naquela localidade já há algum tempo e tinha requerido junto ao governo a medição daqueles terrenos para fundar sua aldeia. A burocracia da Secretaria de Estado dos Negócios de Obras Públicas e Colonização, após considerar a Lei $\mathrm{n}^{\circ} 601$ de 18 de setembro de 1850, o Decreto $\mathrm{n}^{\circ} 1.318$ de 30 de janeiro de 1854 do governo imperial, e a Lei $\mathrm{n}^{\circ} 68$ de 20 de dezembro de 1892 em seu artigo 19 que determinava que o governo poderia reservar terras para a fundação de colônias, emitiu uma sentença para expedição do título de terras ao cacique Timotheo, como segue:

\begin{abstract}
O Dr. Manoel Alencar Guimaraes, Presidente do Congresso Legislativo em exercício no cargo de Governador do Estado.

Faz saber que tendo o Capitão Timoteo, chefe da tribu dos coroados e a mais 40 individuos da mesma tribu obtido por uso fruto nos termos do art $^{\circ} 75$ do Decreto ${ }^{\circ} 1318$ de 30 de janeiro de 1854, uma área de terras contendo oito milhões trezentos e setenta e sete mil e oitocentos e oitenta e nove metros quadrados ou (837, h78, a, 89c hectares) no município de "Tibagi" se acha o mesmo Capitão Timoteo, chefe da tribu dos Coroados e mais 40 da mesma tribu, pelo presente titulo, investido do direito de domínio direto sobre as terras contidas na referida área, salvo direito de terceiros e respeitados as prescrições das leis e regulamentos em vigor. ${ }^{28}$
\end{abstract}

A versão dos Kaingang da Terra Indígena Mococa não é a mesma descrita no documento de titulação fornecido pela burocracia do Estado. O Sr. Augusto Merenciano Kogoia, neto do velho cacique Timotheo, contou que seu avô comprou do governo aquelas terras.

28 A Secretaria do Estado dos Negócios de Obras Públicas e Colonização do Paraná registrou o título das terras "doadas" ao capitão Timotheo no livro terceiro de 1903, à folha 225. Esse documento pode ser localizado no Arquivo Público do Paraná em Curitiba no Relatório da Secretaria do Estado dos Negócios de Obras Públicas e Colonização, 1903. A Regional do SPI do Paraná fez uma cópia desse documento que foi arquivado na sua documentação que utilizamos aqui. Cf. SPILTN IR. Filme 74, fotograma 292. 
Meu avô (Capitão Velho Timótheo = Timotheo Gojé) morava lá no Laranjinha. Ele foi procurar uma morada para morar longe. Mas naqueles tempos não tinha estrada, só mato. Então ele veio só pelo Rio Tibagi. Ele veio com o poder da água. Vieram 25 famílias do Laranjinha. Tinham doze canoas pra ele carregar família e carregar coisa pra comer também. Meu avô tinha quatro filhas e tinha quatro homens. Trouxe todos por dentro da água pelo Rio Tibagi.

Daí eles fizeram os ranchos para morar, aqui pra baixo. Plantaram milho, arroz, feijão. Foram olhar os peixes no rio. E então eles foram lá para Curitiba, pedir um lugar bom para morar, pedir terreno. Aí o governo falou: 'O que vocês vieram pedir para mim?' 'Eu vim pedir terra, um chão para morar.' E o governo disse que não dava, mas podia vender. Os Kaingang falaram que queriam quinhentos alqueires de terra e o Governo de Curitiba disse que vendia por 100 mil réis. (CASÃO, 2007: 40 $)^{29}$

Conforme a narrativa do Sr. Augusto, os Kaingang comandados pelo seu avô tiveram que pagar $100 \$ 000$ (cem mil réis) pelas terras. Como não tinham o dinheiro, foram trabalhar numa empreitada de derrubada de mato para o governo e com isso quitaram a dívida. Foi dessa forma que cacique Timotheo conseguiu do governo estadual a titulação de uma parcela de 837 hectares (349 alqueires) de terras na margem esquerda do Rio Tibagi, abaixo do Salto Mauá, em 5 de novembro de 1903.

Mas o grupo kaingang do cacique Timotheo manejava territórios muito mais amplos. Quando da visita da expedição do SPILTN em seu emã, em dezembro de 1910, ele estava caçando distante $12 \mathrm{~km}$ de seu emã. Tanto que o capitão Ozório teve de esperar sua volta para distribuir os brindes, fazer o recenseamento e obter outras informações relativas ao seu grupo.

Na história da migração de seus antepassados, do Rio Laranjinha para o Rio Tibagi, o Sr. Augusto Kogoia descreve os diversos locais onde seu avô e familiares faziam seus waré, tinham suas roças, seus paris e seus cemitérios. Percorriam a Krin-yú-rãn-rãn - Serra Grande, subiam o Rio Tibagi e adentravam seus afluentes, como Ribeirão Mococa, Rio Dó Kané bang - Barra Grande, e muitos outros.

Ocorre aqui uma situação que ilustra o que acontecia na maioria das outras áreas demarcadas para os índios nesse início de século: apesar do emã estar situado dentro de limites demarcados, os grupos familiares se deslocava para fora desses limites manejando

29 As narrativas do Sr. Augusto Merenciano Kogoia foram feitas para Carolina Dias Cunha Casão, Kimiye Tommasino e Lúcio Tadeu Mota que estiveram com ele na TI Mococa em 2003. Carolina D. C. CASÃO fez outras entrevistas, organizouas e publicou em sua monografia de especialização: Produção e reprodução cultural na Terra Indígena Mococa: os Kaingang e suas relações com a natureza, defendida no Curso de Especialização em Ensino de Sociologia da Universidade Estadual de Londrina em 2007. Estivemos com o Sr. Augusto em outras oportunidades (2008 e 2010) e ele recontou a história da compra das terras de Mococa pelo seu avô Timotheo Gojé. 
áreas territoriais muito mais extensas, conforme suas necessidades materiais, socioculturais e religiosas.

E o emã do cacique Timotheo apresenta outra peculiaridade: a presença de famílias Guarani convivendo com seu clã familiar Kaingang. Enquanto ele não chegava, a expedição visitou as duas famílias de Guarani que viviam nas proximidades. Elas estavam em "extrema penúria" e doentes pela varicela. Socorreram os Guarani com latas de leite condensado, remédios, conselhos e dinheiro, "para não sucumbirem a fome e á míngua, naquelle deserto, onde os gemidos dos infelizes nem encontrarião echo nos corações generosos"(OZÓRIO, 1910: 8).

A exuberância do lugar e a solidão daqueles imensos territórios devem ter despertado a generosidade do capitão Ozório para ele ter dado dinheiro para os Guarani, bem como tê-lo inspirado na escrita de seu relatório. Até hoje a TI Mococa é a mais distante de centros urbanos no Paraná. Para se chegar a ela tem-se que viajar $70 \mathrm{~km}$ de estradas de terra desde a cidade de Ortigueira, e o distrito mais próximo é o de Natingui, cerca de $7 \mathrm{~km}$ da sede da TI.

\section{$\checkmark \quad$ Emã Fachinal do Cambará do cacique Ferreira}

A expedição continuou sua viagem pela serras da margem esquerda do Rio Tibagi rumando para vila de Queimadas, atual Ortigueira. Depois de dois dias por picadas quase intransitáveis, chegaram ao emã do cacique Ferreira, denominado pelos nacionais de Fachinal do Cambará.

Situada nos altos da Serra do Cadeado, nos divisores das águas dos Rios Tibagi e Ivaí, ela foi considerada "pitoresca e de aspecto muito agradável". A paisagem local parece ter descansado a vista do capitão Ozório, já acostumada à mataria das margens do Tibagi. Ele escreveu que ela: "ali espraiou-se deliciosamente, numa espécie de desafogo." Habitada por 149 Kaingang, o emã Fachinal do Cambará foi considerado o mais próspero de todos já visitados pela comitiva do SPI. "Os ranchos são de lascas de pinheiro e os índios possuem considerável criação de suínos e alguns cavallos e muares." (OZÓRIO, 1910: 8)

A beleza paisagística e a prosperidade do emã do Cambará contrastaram com a irritação do cacique Ferreira contra as demarcações de terras que os nacionais faziam nas suas imediações, demarcações que o cacique "chamou de bendegó termo de gíria, aplicado ás concessões escandalosas." (OZÓRIO, 1910: 8)

O processo de ocupação dos territórios Kaingang nas imediações da vila de Queimadas ocorria de forma acelerada e deixava o cacique Ferreira zangado diante das autoridades, mesmo após ter recebido a visita das autoridades e os presentes do SPILTN. 


\section{$\checkmark$ emã Faxinalzinho do cacique Alfredo Veigmon}

Mais um dia de viagem e a comitiva da $7^{\mathrm{a}}$ Inspetoria Regional do Paraná chegou ao último local a ser visitado na viagem. Tinham chegado ao emã do Faxinalzinho liderado pelo jovem cacique Veigmon. Alfredo Veigmon estava substituindo seu pai que tinha recémfalecido vítima da varíola. Esse aldeamento tinha os ranchos feitos de lascas de pinheiros como os do Fachinal do Cambará, e a população de 164 pessoas tinha conhecimentos dos modos e da língua dos seus vizinhos nacionais.

Mas o que impressionou o capitão Ozório foi encontrar ali três índios cativos; "escravisados por terem sido prisioneiros em uma batida, há 14 annos passados." (OZÓRIO, 1910: 9) Infortúnio foi o capitão Ozório não ter feito uma descrição desses prisioneiros dos Kaingang, ele apenas dá uma pista: "Ahi encontramos 3 botocudos (...) escravisados." (OZÓRIO, 1910: 9) Botocudos era uma denominação utilizada para todas as populações indígenas que usavam o batoque, espécie de adorno de madeira, cristal, osso, resina, etc. preso nos lábios inferiores. Aqui no Paraná, usavam esses adornos os Xokleng da região do Rio Negro e Iguaçu, os Kayowá do Paranapanema e os Xetá que viviam no vale do Rio Ivaí. Esses prisioneiros ${ }^{30}$ dos Kaingang poderiam com quase certeza ser os Xetá, pois nessa mesma época, em 1910, o naturalista tcheco Albert V. Fric relatou sua participação em uma expedição dos Kaingang, do Salto Ubá no Rio Ivaí, para capturar um grupo Xetá nas serras da margem esquerda do Rio Ivaí. ${ }^{31}$

Passado o espanto, distribuíram os brindes à gente de Veigmon e encerraram as visitas rumando para a cidade de Tibagi onde chegaram no dia 23 de dezembro e dali retornaram para Curitiba onde novos deveres os chamavam: deveriam partir imediatamente para a visita aos índios Xokleng em Santa Catarina.

A situação dos Kaingang nessa região da Serra do Cadeado apresentava duas circunstâncias diferenciadas. Enquanto o cacique Timotheo tinha uma terra demarcada, mas circulava por territórios maiores, os Kaingang liderados pelos caciques Ferreira e Alfredo Veigmon não tinham nenhuma demarcação de seus territórios e estavam sendo espoliados pela frente de ocupação que chegava às encostas do terceiro planalto paranaense.

Essa frente de ocupação, iniciada no final do século XIX, foi acelerada no início do XX, e era constituída de diferentes contingentes populacionais. Havia os homens pobres e livres que viviam nas franjas das grandes fazendas de gado dos Campos Gerais que já faziam esse movimento de deslocamento para oeste em busca de terras "livres" desde o século XIX. Para a região também rumavam os excedentes populacionais de outros Estados, como Minas Gerais, São Paulo e mesmo do chamado Norte Velho do Paraná que vislumbravam a

30 Sobre a captura de grupos Xeta pelos Kaingang, ver Lúcio Tadeu MOTA; Os Xetá no vale do Rio Ivaí - 1840 a 1920. Maringá: Eduem, 2013.

31 Para maiores detalhes sobre a expedição de Fric e os Xetá no vale do Rio Ivaí, ver Lúcio T. MOTA. Os Xetá no vale do Rio Ivaí - 1840 a 1920. Maringá: Eduem, 2013. 
possibilidade de conseguir uma parcela de terras para criar porcos no sistema safrista. Com informações e a proteção de autoridades da capital e das cidades próximas, políticos, grandes fazendeiros e apaniguados do governo local procuravam ampliar seus patrimônios açambarcando grandes extensões de terra, conseguindo concessões escandalosas em verdadeiros "bendegó" no dizer do cacique Ferreira. E por fim, uma parcela menor, mas a mais perigosa, da população que chegava à vila de Queimadas, a dos foragidos da justiça que se internavam naquelas serras com a intenção de fugir da justiça e continuar seus malfeitos. Eram esses indivíduos os recrutados pelos grandes grileiros para limpar as terras: seja dos nacionais pobres que tinham usucapião de seus terrenos ou dos Kaingang que estavam nesses territórios.

Essa frente de ocupação heterogênea, mas determinada a conseguir propriedades de terras, ameaçava deixar os Kaingang sem seus territórios antes que o governo os demarcassem. Essa era a situação enfrentada pelos caciques Ferreira e o jovem Veigmon. E eles fizeram suas queixas ao representante do governo federal contra o esbulho dos seus territórios. O Relatório do capitão Ozório chegou ao SPILTN no Rio de Janeiro no início de 1911. As autoridades federais tomaram conhecimento da situação da Serra do Cadeado e alguns anos depois o governo do Estado do Paraná emitiu o Decreto 591 de 17/8/1915, demarcando as terras para os Kaingang da Serra do Cadeado.

Decreto No. 591 de 17 de Agosto de 1915.

O Presidente do Estado do Paraná usando da autorisação contida na Lei N. ${ }^{\circ} 1.168$ de 16 de Abril de 1.912, e tendo em vista garantir a propriedade da lavoura dos indios Caigangs estabelecidos nos toldos denominados Faxinalsinho, Palmital e Faxinal do Cambará, decreta:

Art. 1. ${ }^{\circ}$ Fica reservada para o estabelecimento dos índios Caigangs dos toldos denominados Faxinalsinho, Palmital e Faxinal do Cambará, no Municipio de Tibagy, salvo direito de terceiros, uma área de terras comprehendidas nos seguintes limites: Principiando na barra do rio do Rosario no rio Alonza, por este acima até a barra do arroio Bonito, por este acima até a primeira vertente acima da Pedra Branca, por esta vertente acima até a serra a procura de uma vertente que desagua ao lado esquerdo do arroio dos Poços, por este abaixo até o ribeirão das Formigas, e por este abaixo até o rio Barra Grande, por este acima até as cabeceiras, d'ahi pela divisa da fazenda da Apucarana até a cabeceira do rio Rosario e por este abaixo até a sua fóz onde começou.

Art. 2. ${ }^{\circ}$ Revogam-se as disposições em contrario.

Palácio da Presidência do Estado do Paraná, em 17 de Agosto de 1915; $27^{\circ}$ da Republica.

Carlos Cavalcanti de Albuquerque

Marins Alves de Camargo (PARANÁ, Decreto 591, de 17 de Agosto de 1915)

O Decreto 591 demarcou os territórios Kaingang também na vertente da serra do lado da bacia do Rio Ivaí. Os Kaingang desses emãs do alto da Serra do Cadeado tinham conexões com os grupos Kaingang da bacia do Rio Ivaí. 
Terminada a viagem, o capitão Ozório contabilizou 12 aldeias visitadas e recenseou 1.044 índios. Admitindo poder haver falhas na contagem, acrescentou $10 \%$ chegando a um total presumível de 1.148 indígenas vivendo no vale do Rio Tibagi no final de 1910.

Essa população era na sua maioria da etnia Kaingang, mas havia os Guarani Ñandewá e os Kayowá vivendo no baixo Rio Tibagi no tekoha Tirafubá. No emã do cacique Timotheo, ele encontrou famílias Guarani convivendo junto com o grupo Kaingang, e em um terceiro emã, o do Faxinalzinho, já no divisor de águas dos Rios Tibagi com o Ivaí, ele encontrou três Xetá morando com os Kaingang.

Quadro 2. Emãs Kaingang e Tekohas Guarani visitados pelo capitão José Ozório em dezembro de 1910.

\begin{tabular}{|c|c|c|c|c|c|c|}
\hline $\mathbf{N}$ & Nome & Data da visita & Localização aproximada & Cacique & Etnia & Pop. \\
\hline 01 & $\begin{array}{l}\text { Boa Vista da } \\
\text { Apucarana }\end{array}$ & $\begin{array}{c}6 \text { e } 7 \text { de } \\
\text { dezembro de } \\
1910\end{array}$ & $\begin{array}{l}20 \text { km de São Jerônimo no } \\
\text { alto da Serra da Apucarana }\end{array}$ & $\begin{array}{l}\text { Ignácio } \\
\text { Chocanban }\end{array}$ & Kaingang & 114 \\
\hline 02 & $\begin{array}{l}\text { Foz do } \\
\text { Apucaraninha }\end{array}$ & $\begin{array}{l}7 \text { de dezembro } \\
\text { de } 1910\end{array}$ & $\begin{array}{l}\text { Margem esquerda da foz do } \\
\text { Apucaraninha no Tibagi. }\end{array}$ & $\begin{array}{l}\text { Chico } \\
\text { Telêmaco }\end{array}$ & Kaingang & 21 \\
\hline 03 & Barra do Tigre & $\begin{array}{c}8 \text { de dezembro } \\
\text { de } 1910\end{array}$ & $\begin{array}{l}\text { Foz do Rio do Tigre no Tibagi, } \\
\text { margem direita }\end{array}$ & $\begin{array}{l}\text { Cacique } \\
\text { Siqueira }\end{array}$ & Kaingang & 18 \\
\hline 04 & $\begin{array}{l}\text { Toldo da } \\
\text { Limeira }\end{array}$ & $\begin{array}{c}8 \text { e } 9 \text { de } \\
\text { dezembro de } \\
1910\end{array}$ & $\begin{array}{l}\text { No alto da serra de São } \\
\text { Jerônimo a } 920 \text { metros de } \\
\text { altitude }\end{array}$ & $\begin{array}{l}\text { Cacique Julio } \\
\text { Feio }\end{array}$ & Kaingang & 118 \\
\hline 05 & $\begin{array}{l}\text { Engenho de } \\
\text { Ferro }\end{array}$ & \multirow{3}{*}{$\begin{array}{c}12 \text { a } 15 \text { de } \\
\text { dezembro de } \\
1910\end{array}$} & \multirow{3}{*}{$\begin{array}{l}\text { Receberam a visita dos } \\
\text { caciques e lideranças na sede } \\
\text { da Colônia Militar do Jataí }\end{array}$} & \multirow{3}{*}{$\begin{array}{l}\text { Não } \\
\text { informou o } \\
\text { nome dos } \\
\text { Caciques }\end{array}$} & \multirow{3}{*}{ Kaingang } & \multirow{3}{*}{111} \\
\hline 06 & Poço Bonito & & & & & \\
\hline 07 & Limoeiro & & & & & \\
\hline 08 & Tirafubá & $\begin{array}{c}12 \text { a } 15 \text { de } \\
\text { dezembro de } \\
1910\end{array}$ & $\begin{array}{l}\text { Receberam a visita dos } \\
\text { caciques e lideranças na sede } \\
\text { da Colônia Militar do Jataí }\end{array}$ & $\begin{array}{l}\text { Não } \\
\text { informou o } \\
\text { nome dos } \\
\text { Caciques }\end{array}$ & $\begin{array}{l}\text { Guarani e } \\
\text { Kayowá }\end{array}$ & 104 \\
\hline 09 & Lambari & $\begin{array}{c}16 \text { de dezembro } \\
\text { de } 1910\end{array}$ & $\begin{array}{l}\text { Distante } 35 \mathrm{~km} \text { a leste de São } \\
\text { Jerônimo }\end{array}$ & $\begin{array}{l}\text { Cacique } \\
\text { Candido }\end{array}$ & Kaingang & 97 \\
\hline 10 & Palmital & $\begin{array}{c}17 \text { de dezembro } \\
\text { de } 1910\end{array}$ & Atual TI Mococa & $\begin{array}{l}\text { Cacique } \\
\text { Timotheo }\end{array}$ & $\begin{array}{l}\text { Kaingang } \\
\text { e Guarani }\end{array}$ & $?$ \\
\hline 11 & $\begin{array}{l}\text { Faxinal do } \\
\text { Cambará }\end{array}$ & $\begin{array}{c}19 \text { de dezembro } \\
\text { de } 1910\end{array}$ & $\begin{array}{l}\text { Proximidades da TI } \\
\text { Queimadas }\end{array}$ & $\begin{array}{l}\text { Cacique } \\
\text { Ferreira }\end{array}$ & Kaingang & 149 \\
\hline 12 & Faxinalzinho & $\begin{array}{c}20 \text { de } \\
\text { dezembro de } \\
1910\end{array}$ & $\begin{array}{l}\text { Proximidades da TI } \\
\text { Queimadas }\end{array}$ & $\begin{array}{l}\text { Cacique } \\
\text { Alfredo } \\
\text { Veigmon }\end{array}$ & $\begin{array}{l}\text { Kaingang } \\
\text { e Xetá }\end{array}$ & 164 \\
\hline & \multicolumn{5}{|c|}{ Total da população indígena calculada pelo Capitão na bacia do Rio Tibagi no final de 1910.} & 1.148 \\
\hline
\end{tabular}


Com a expansão da sociedade nacional, houve a diminuição de aldeias e dos territórios ocupados. Essa diminuição atingiu seu auge em 1949 e hoje há um processo de retomada de antigas áreas. A população continuou crescendo. Se em 1910 eram 1.148 pessoas, hoje são quase 3.500 distribuídas em cinco Terras Indígenas.

Quadro 3: Situação atual das Terras Indígenas na bacia do Rio Tibagi.

\begin{tabular}{|c|c|c|c|c|c|c|}
\hline \multicolumn{7}{|c|}{ Bacia do Rio Tibagi } \\
\hline $\mathbf{N}$ & $\begin{array}{c}\text { Terras } \\
\text { Indígenas }\end{array}$ & Etnias & Município(s) & Situação fundiária & Área (Ha) & \begin{tabular}{|c} 
População \\
Funasa \\
2010
\end{tabular} \\
\hline 01 & Apucarana & Kaingang & Tamarana & $\begin{array}{l}\text { Registrada. Situação atual: os Kaingang } \\
\text { reivindicam uma área de } 725 \text { ha em } \\
\text { posse da empresa Nutrimental } \\
\text { Agropecuária Ltda. }\end{array}$ & 5.575 & 1.647 \\
\hline 02 & \begin{tabular}{|l|} 
Barão de \\
Antonina
\end{tabular} & Kaingang & $\begin{array}{l}\text { São Jerônimo } \\
\text { da Serra }\end{array}$ & Registrada no SPU (1977) e no CRI (1992) & 3.750 & 474 \\
\hline 03 & \begin{tabular}{|l|} 
São \\
Jerônimo
\end{tabular} & $\begin{array}{l}\text { Kaingang } \\
\text { Guarani } \\
\text { Xetá }\end{array}$ & $\begin{array}{l}\text { São Jerônimo } \\
\text { da Serra }\end{array}$ & Registrada no SPU (1977) e no CRI (1992) & 1.339 & 586 \\
\hline 04 & Mococa & Kaingang & Ortigueira & Registrada no SPU (1996) & 859 & 163 \\
\hline 05 & Queimadas & Kaingang & Ortigueira & Registrada no CRI (1996) e no SPU (1998) & 3.077 & 543 \\
\hline & Total & & & & 14.600 & 3.413 \\
\hline
\end{tabular}


Mapa 1. Bacia do Rio Tibagi com os aldeamentos Kaingang, Kaiowá e Guarani em 1910.

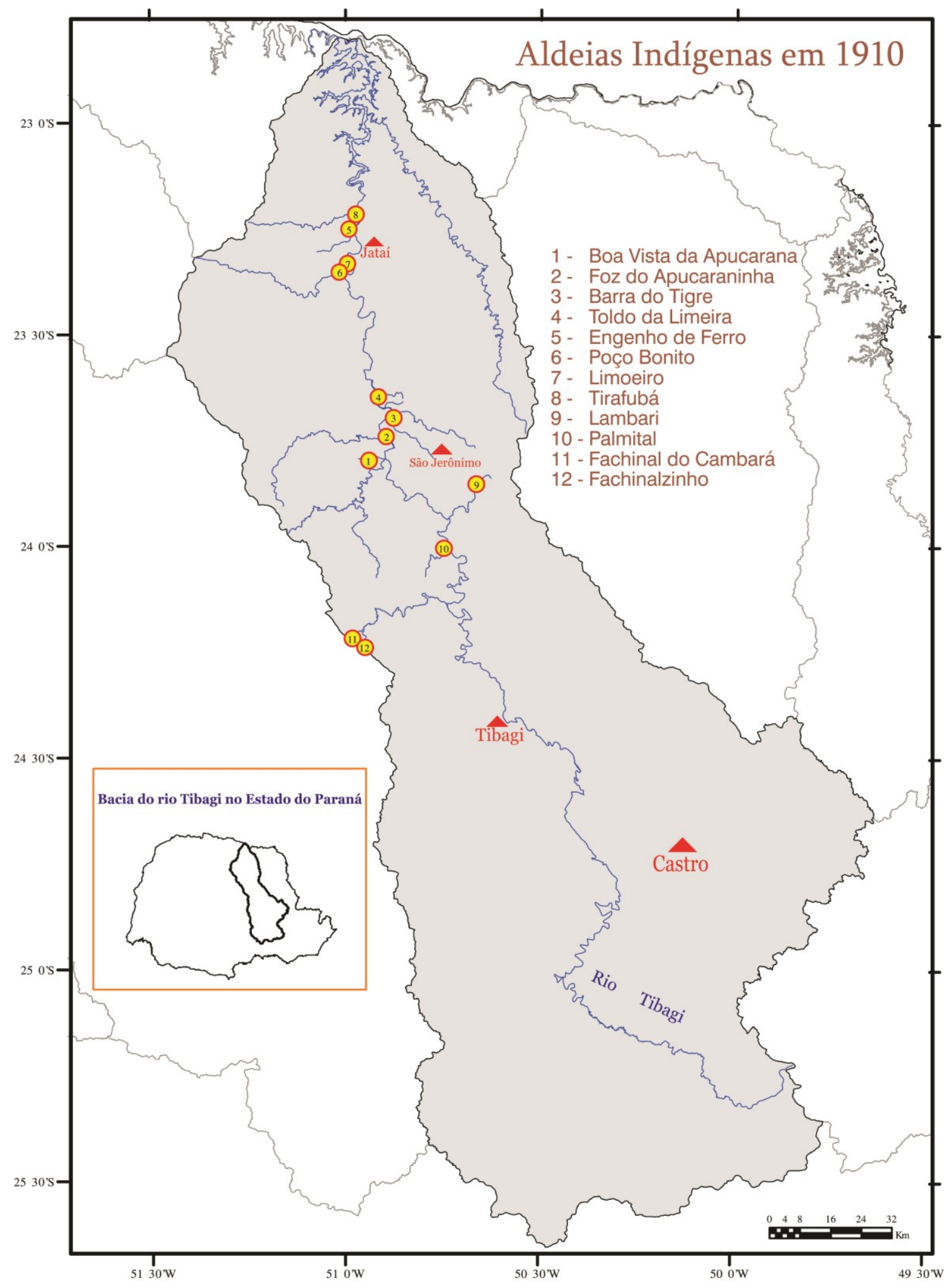

Fonte. Lúcio Tadeu Mota e Marcos Rogério de Oliveira. 


\section{Conclusão}

Com o advento da República passou a haver três processos de ocupação dos territórios indígenas. $O$ primeiro foi a continuidade do que já havia ocorrido na colônia e no império, isto é, a invasão dos territórios indígenas pelas frentes de ocupação documentadas ou não. A ação individualizada ou de grupos de pessoas em direção aos território indígenas, então considerados pelo Estado como de terras "devolutas", ocorreu sem o controle estatal. Ela agiu de diversas formas: desde a aproximação pacífica dos territórios indígenas e estabelecimento com eles de relações sociais de boa vizinhança, até formas beligerantes de conflitos armados com a expulsão dos indígenas, como o que estava acontecendo no vale do Rio das Cinzas em 1910.

Os dois outros processos foram chancelados pelo poder público com suas políticas de "defesa" das populações indígenas. Um deles foi a atuação dos governos estaduais que passaram a administrar esses territórios como terras consideradas devolutas e colocá-los à disposição para projetos de colonização. No Paraná, a nova política de desterritorialização dos índios passou a ser feita com os diversos decretos estaduais que, se por um lado reservou e limitou as áreas de terras de uso dos indígenas, por outro liberou para negociações vastas extensões de territórios que estavam sob o manejo dos indígenas. O outro foi a ação da União que, por meio do SPILTN, passou a implantar as Povoações Indígenas com o intuito de transformar os indígenas em agricultores fixados em lotes de terra vivendo como os nacionais e produzindo mercadorias para o mercado nacional e internacional.

Os indígenas fizeram a leitura dessa nova conjuntura política, estabeleceram estratégias e pontuaram demandas para defesa de seus territórios e daquilo que eles entendiam ser significativo em suas sociedades.

A primeira delas foi estabelecer aliança com o poder republicano mostrando para a frente de ocupação que eles não estavam sozinhos em sua luta, iriam ter daquele momento em diante um aliado: a República. Deram visibilidade a essa aliança visitando a comitiva do SPILTN em São Jerônimo "marchando garbosamente (...) como desfile marcial".

Mas antes de apresentar suas demandas ao novo aliado, tiveram que ouvir do capitão Ozório qual era a política do SPILTN para os indígenas e suas opiniões sobre eles. Ouviram que estavam numa encruzilhada. Para o militar positivista, eles viviam um dilema, dizendolhes que: "o índio, ou jaz inculto e inútil para a sociedade moderna, ou civiliza-se e degradase.” (OZÓRIO, 1910: 15) Na sua perspectiva, os indígenas não teriam futuro se continuassem a conviver com os nacionais das povoações do entorno de suas aldeias. Eles estavam condenados à degradação, pois naquelas zonas fronteiriças não havia civilização suficiente para passar os indígenas de seu estado "selvagem" para o "civilizado", e antes que misturassem com as populações caboclas das fronteiras e por elas fossem corrompidos, eles 
seriam auxiliados pelo governo nacional. "Antes que muitas populações se estraguem nessa evolução empírica, urge irmos em seu auxilio, illuminando-lhes os espíritos e despertandolhes os sentimentos nobres." (OZÓRIO, 1910: 16) Dessa forma, o capitão Ozório sintetizou a missão do SPILTN pregada por seus fundadores e escrita no Decreto n. 8.072 de 20/6/1910.

Assim como tinham ouvido dos padres jesuítas, há quatrocentos anos, que eles estavam ali para salvar suas almas; como tinham ouvido dos freis capuchinhos, cinquenta anos antes, que eles seriam salvos aqui na terra com a "civilização" e suas almas seria salvas no outro mundo com a "catequese", agora ouviam que seriam protegidos e iluminados pelo governo republicano. O projeto do SPILTN para auxiliar os indígenas e "iluminar" seu caminho rumo ao "progresso" passava por implantar as Povoações Indígenas, fixá-los em lotes de terra com moradias nos moldes dos trabalhadores nacionais e ensiná-los a serem agricultores.

A ideia de que os índios poderiam se tornar agricultores inseridos no processo produtivo eles já conheciam e expunham às autoridades do Paraná toda vez que viajavam a Curitiba para reivindicar demarcação de terras e solicitar ferramentas agrícolas. Portanto, ouvir de alguma autoridade do governo a proposição de que eles se tornassem agricultores significava a demarcação de terras, o fornecimento de ferramentas, sementes e implementos, que nem sempre eram utilizados na agricultura. Criar a Povoação Indígena e fixá-la em lotes com moradias, também não era novidade. Desde há muito tempo cada grupo familiar tinha seus locais de plantio, de coleta e caça, e algo parecido com a povoação indígena também já existia desde a implantação das Colônias Indígenas de São Pedro de Alcântara e São Jerônimo em meados da década de 50 do século XIX. A novidade era a possibilidade de terem casas novas e a área da Povoação Indígena ser protegida de invasões, como estava sendo, pelo governo federal.

O projeto do SPILTN era de longo prazo e poderia ser ressignificado como tinham feito com a política das Colônias Indígenas implementadas pelo governo Imperial. Sabiam que com o tempo eles o adaptariam ao seu modo de vida. $\mathrm{O}$ mais urgente era a defesa de suas terras que estavam sendo invadidas tanto de forma legal pelo Estado do Paraná como de forma ilegal pelas populações que chegavam na região.

A segunda ação foi, ao receber a comitiva do SPILTN em seus emãs e tekohas, expor ao representante do governo federal que eles estavam sendo expropriados de seus territórios pela ação das frentes de ocupação e pelas demarcações de terras autorizadas pelo governo do Paraná. Se no vale do Rio das Cinzas havia a guerra de fronteira, os Kaingang defendiam com armas seus territórios. No vale do Rio Tibagi essa questão se revela como "magna questão das terras", no Relatório do capitão Ozório. Onde: 
(...) o índio tem na disputa da posse da terra que habita, um continuo pesadello e a causa quase exclusiva, de sanguinolentos conflitos que de tempos em tempos, perturbão a cordialidade de suas relações com os ocidentais. Foi objecto especial de nossas investigações, a magna questão das terras. (OZÓRIO, 1910: 11)

Mas a "magna questão das terras" tinha vários gradientes e tomava diversos rumos conforme a ação dos grupos indígenas em seus embates com a sociedade envolvente.

Um deles era a dos grupos que estavam assentados em áreas já definidas desde o século XIX como era o caso dos emás do Rio do Tigre e da Limeira que estavam nos limites da fazenda São Jerônimo. $O$ da Boa Vista da Apucarana definido pelo Decreto $n^{0} 6$, de 5 de julho de 1900. E os do Engenho de Ferro e Poço Bonito que os indígenas afirmaram ter documentos conforme a Lei $n^{\circ} 1$ de 1893. A atuação dos indígenas tinha garantido, até aquele momento, essas áreas, no entanto em 1949, elas vão ser redefinidas com uma drástica diminuição.

Outra situação foi a apresentada pelos caciques Guarani Ñandewa e Kayowá do baixo Tibagi. Argumentaram que tinha sido expulsos de suas terras por alguém que tinha conseguido documentação junto ao Estado. Também aparece nas queixas dos caciques Ferreira e Veigmon na Serra do Cadeado, que, irritados com a situação, denunciaram e esbulho de suas terras com as demarcações autorizadas. Elas foram anotadas no Relatório que foi enviado ao SPILTN no Rio de Janeiro no início de 1911. Alguns anos depois, o governo do Estado do Paraná emitiu o Decreto 591 de 17/8/1915, demarcando terras para os Kaingang. A demarcação dos territórios Kaingang na Serra do Cadeado em 1915 evidencia o resultado da estratégia e das ações das lideranças indígenas junto às autoridades federais.

Um terceiro modo era a dos emás que estavam fora dos limites demarcados pelos decretos estaduais do início do século XX. São as aldeias do Apucaraninha, do Limoeiro e Lambari. Eram locais de ocupação tradicional que os indígenas teimavam em manter mesmo com a determinação do governo do Estado de que eles deveriam instalar suas aldeias apenas no interior de áreas já definidas por lei.

Havia ainda a situação das terras do cacique Timotheo que as tinha comprado do governo do Estado. Uma situação atípica e diferente de todas as outras estratégias de manter uma porção de seus territórios.

Apesar desse gradiente de situações que mostra a complexidade das relações em torno da defesa de parcelas de seus territórios, havia uma ação comum em todos os grupos indígenas: todos eles manejavam territórios que iam muito além dos definidos pelo Estado, como é caso do cacique Timotheo que, no momento da visita do capitão Ozório, estava a muitos quilômetros de sua aldeia. 
A terceira estratégia foi apresentar à comitiva do SPILTN que estavam sendo enganados no comércio que faziam com seus vizinhos. Tanto que o capitão Ozório anotou que os nacionais abusavam da "ingenuidade do pobre selvicola". (...) o logro desumano pelo qual geralmente terminão os negócios, gerarão no intimo do selvagem, uma atmosphera de desconfiança de todo justificada. (OZÓRIO, 1910: 14). E nas palavras do capitão Ozório essa situação teria um fim, pois os indígenas "estavão, muito confiantes na ação governamental, para que dia a dia apellão suplicas" (OZÓRIO, 1910: 14). Os índios queriam um comércio justo, sem imposição de preços abaixo do mercado para suas mercadorias, ou sobre preços nas mercadorias que compravam. Não queriam logro nos negócios com os brancos.

E uma quarta estratégia era a manutenção de seus costumes em seus emás e tekohas. Se a frente de expansão que se espalhava pelo vale do Tibagi impactava os costumes antigos dos Kaingang, fazendo os adaptar, transformar o wãxi, tempo antigo, no uri, tempo novo, ainda podia perceber vários aspectos tradicionais da vida social dessas populações presentes nas aldeias. A manutenção dessas formas tradicionais de vida significava resistência às imposições da catequese no período imperial e as do Estado laico pós-república. Essas formas tradicionais de vida se materializavam na construção de wãre (ranchos provisórios) e no ritual de enterramento de uma criança no emá de Boa Vista da Apucarana; na poligamia do cacique da Barra do Rio do Tigre e nos toques de buzina anunciando a chegada da comitiva do SPILTN na aldeia da Limeira.

A história das relações socioculturais dos indígenas com a sociedade envolvente e com o Estado republicano vão muito além das explicações polarizadas e simplificadas: índios versus brancos ou o inverso. São situações complexas porque os sujeitos históricos são diferenciados e as relações são desiguais, mas também combinadas. Desiguais porque não existe simetria das sociedades indígenas com a sociedade envolvente, e combinadas porque mesclam formas tradicionais de vida com as novas configurações socioeconômicas impostas pelas relações capitalistas. A atuação dos indígenas nessa conjuntura, se por um lado fez com que eles tivessem que readequar aspectos de seus modos de vida tradicionais às novas situações, por outro garantiu a sua existência no vale do Rio Tibagi.

\section{Bibliografia}

BALANDIER. Georges. A noção de situação colonial. Cadernos de Campo. São Paulo: USP, vol. 3. p. 107-131, 1993.

BARBOSA, Luiz Bueno Horta. O Serviço de Proteção aos Índios e a história da colonização do Brasil. Rio de Janeiro: Typografia do Jornal do Commercio, 1919.

BARBOSA, Luiz Bueno Horta. Pelo índio e pela sua protecção official. Rio de Janeiro: Typ. Macedo, 1923. 


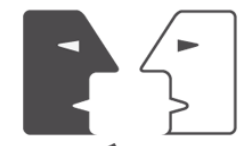

ANTÍTESES

BARTH, Fredrik. Los grupos étnicos y sus fronteras. México D. F.: Fondo de Cultura Econômica, 1976.

BORBA, Telêmaco. Actualidade indigena. Curitiba: Impressora Paranaense, 1908.

BORBA, Telêmaco. Breve noticia sobre os índios Caingangs, conhecidos vulgarmente por Coroados e que habitam no território da Província do Paraná. IN: Chorographia do Paraná. Curitiba: Livraria Econômica, 1899, p. 331-344.

BORBA, Telêmaco. Observações sobre os indígenas do Estado do Paraná. Revista do Museu Paulista. São Paulo: Typographia do Diário Oficial, vol. 6, p. 53-62, 1904.

BORBA, Telêmaco. Pequeno Vocabulário das Línguas Portuguesa e Caingangs ou Coroados. IN: Almanach do Paraná. Curitiba: Livraria Econômica, 1903, p. 201-205.

BRASIL. Constituição (1891). Constituição da República dos Estados Unidos do Brasil. Disponível em: <http://www.planalto.gov.br/ccivil_03/constituicao/constituicao91.htm> Acesso em 17/03/2014.

BRASIL. Decreto $\mathrm{n}^{0}$ 9.214, de 15 de dezembro de 1911. Regulamento do Serviço de Protecção aos Indios e Localização de Trabalhadores Nacionaes. Disponível em: $<$ http://legis.senado.gov.br/legislacao/ListaPublicacoes.action?id=53816> Acesso em17/03/2014.

BRASIL. Decreto $\mathrm{n}^{\circ}$ 8.072, de 20 de junho de 1910. Crêa o Serviço de Protecção aos Indios e Localização de Trabalhadores Nacionaes e approva o respectivo regulamento. Disponível em: $\quad<$ http://www2.camara.leg.br/legin/fed/decret/1910-1919/decreto-8072-20-junho-1910504520-norma-pe.html> Acesso em 17/03/2014.

BRASIL. Lei Orçamentária $\mathrm{n}^{\circ}$. 3.454, de 6 de janeiro de 1918. Fixa a Despeza Geral da Republica dos Estados Unidos do Brasil para o exercicio de 1918. Disponível em: <http://www2.camara.leg.br/legin/fed/lei/1910-1919/lei-3454-6-janeiro-1918-571960-

publicacaooriginal-95095-pl.html> Acesso em 17/03/2014.

BRASIL. Relatório do Ministério da Agricultura, Industria e Comercio 1910-1911. Rio de Janeiro: Officinas da Diretoria Geral de Estatística, 1911, p. 55.

BRASIL. SPILTN. $7^{\text {a }}$ Inspetoria Regional do Paraná. Filme 74, fotograma 292. Rio de Janeiro: Museu do Índio.

BRASIL. SPILTN. $7^{\mathrm{a}}$ Inspetoria Regional do Paraná. Filme 75, fotogramas 0020 a 0030 . Museu do Índio, Rio de Janeiro. Rio de Janeiro: Museu do Índio. 
BRASIL. SPILTN. $7^{\mathrm{a}}$ Inspetoria Regional do Paraná. Filme 75, fotograma 2.035. Rio de Janeiro: Museu do Índio.

BRASIL. SPILTN. $7^{\mathrm{a}}$ Inspetoria Regional do Paraná. Filme 80, fotogramas 0215-0277. Rio de Janeiro: Museu do Índio.

BRASIL. SPILTN. $7^{\text {a }}$ Inspetoria Regional do Paraná. Filme 80, fotograma 206. Rio de Janeiro: Museu do Índio.

CARMACK, Robert M. Etnohistoria y teoria antropológica. Cuadernos del Seminario de Integración Social Guatemalteca, Guatemala, Ministério de Educacion, v. 26, p. 7-47, 1979.

CASÃO, Carolina Dias Cunha. Produção e reprodução cultural na Terra Indígena Mococa: os Kaingang e suas relações com a natureza. Monografia de Especialização em Sociologia, Universidade Estadual de Londrina, 2007.

CAVALCANTI, J. B. Exposição sobre as terras da povoação de S. Jeronymo, apresentada ao Miguel Calmon du Pin e Almeida. Rio de Janeiro: Imprensa Nacional, 1924.

CAVAlCANTI, J. B. Exposição sobre o Serviço de Proteção aos Índios e localização de Trabalhadores Nacionaes constante do Relatório do Sr. Ministro da Agricultura, Industria e Commercio relativo ao anno de 1911. Rio de Janeiro: Ministério da Agricultura, Industria e Commercio, 1913.

CUNHA, Manuela Carneiro da. História dos índios no Brasil. São Paulo: Cia. das Letras, 1992.

FRANCO, Arthur Martins. Em defesa do índio e do sertanejo contra "O Serviço de Proteção aos índios e Localização de Trabalhadores Nacionais” no Estado do Paraná. Curitiba: Cia. Editora O Estado do Paraná, 1925.

FRANCO, Arthur Martins. O Coronel Telêmaco Morosini Borba. Curitiba: Arquivos do Museu Paranaense. Curitiba, vol. 1, p. 143-148, 1941.

FREIRE, Carlos Augusto da Rocha. Memória do SPI: textos, imagens e documentos sobre o Serviço de Proteção aos Índios (1910-1967). Rio de Janeiro: Museu do Índio-Funai, 2011.

GAGLIARDI, José Mauro. O indígena e a república. São Paulo: Hucitec, 1989.

HANNERZ, Ulf. Fluxos, fronteiras, híbridos: palavras-chave da antropologia transnacional. Mana. Rio de Janeiro: n. 3, v. 1, p. 7-39, 1997.

LIMA, Antonio Carlos de Souza. O governo dos índios sob a gestão do SPI. IN: História dos índios no Brasil. 2. ed. São Paulo: Companhia das Letras, 1998. 
LIMA, Antônio Carlos de Souza. Um grande cerco de paz: poder tutelar e indianidade no Brasil. Petrópolis: Vozes, 1995.

LÖWY, Michael. La théorie du développement inégal et combiné. Actuel Marx. Paris: Presses Universitaires de France (PUF), vol. 18, p. 111-120, 1995.

MOREIRA NETO, Carlos de Araújo. A política indigenista brasileira durante o século XIX. Tese de Doutorado em Antropologia, FFCL de Rio Claro, Rio Claro, 1971.

MOTA, L. T.; BONNICI, T. A história do vale do rio Tibagi. Texto inédito do engenheiro inglês Thomas P. Bigg-Wither. IN: A natureza dos rios: história, memória e territórios. Curitiba: Editora UFPR, 2008, p. 171-207.

MOTA, L. T.; NOELLI, F. S.; TOMMASINO, K. Uri e Wãxi: estudos interdisciplinares dos Kaingang. Londrina: Eduel, 2000.

MOTA, Lúcio Tadeu. A Construção do "vazio demográfico" e retirada da presença indígena da história social do Paraná. PÓS-HISTÓRIA: Revista de Pós-Graduação em História. Assis: Universidade Estadual Paulista, vol. 2, p. 123-137, 1994.

MOTA, Lúcio Tadeu. As cidades e os povos indígenas: mitologias e visões. Maringá: Eduem, 2008.

MOTA, Lúcio Tadeu. As colônias indígenas no Paraná provincial. Curitiba: Aos Quatro Ventos, 2000.

MOTA, Lúcio Tadeu. As Guerras dos Índios Kaingang: a história épica dos índios Kaingang no Paraná (1769-1934). Maringá: Eduem, 1994.

MOTA, Lúcio Tadeu. Os índios Kaingang e seus territórios nos campos do Brasil meridional na metade do século passado. IN: Uri e Wãxi: estudos interdisciplinares dos Kaingang. 1. ed. Londrina: Eduel, 2000.

MOTA, Lúcio Tadeu. Os Xetá no vale do Rio Ivaí 1840-1920. 1. ed. Maringá: Eduem, 2013.

OLIVEIRA FILHO, João Pacheco de. Ensaios de Antropologia Histórica. Rio de Janeiro: UFRJ, 1999.

OZÓRIO, José. Relatório apresentado à Diretoria Geral, Anno de 1910. SPILTN, Filme 73, fotogramas 2345-2368. Rio de Janeiro: Museu do Índio.

PARANÁ (Estado). Decreto no 591 de 17/8/1915. In: PARANÁ (Estado). Coleção de Decretos e Regulamentos de 1915. Curitiba: Typ. da República, 1915 
PARANÁ (Estado). Decreto $\mathrm{n}^{0}$ 1.606, de 29/12/1906. IN: PARANÁ (Estado). Leis, Decretos e Regulamentos do Estado do Paraná de 1906. Curitiba: Typ. da Penitenciária do Ahú, 1907

PAULA, José Maria de. Terra dos Índios. Rio de Janeiro: Ministério da Agricultura, 1944.

RIBEIRO, Darcy. A política indigenista brasileira. Rio de Janeiro: Ministério da AgriculturaServiço de Informação Agrícola, 1962.

RONDON, Candido Mariano da Silva. Rumo ao oeste: conferência realizada pelo general Rondon no D.I.P. em 30-IX-40 e discursos do Dr. Ivan Lins e do general Rondon, pronunciados na Associação Brasileira de Educação. Rio de Janeiro: Biblioteca Militar, 1942.

SILVA. Francisco Xavier da. Mensagem ao Congresso Legislativo do Estado do Paraná pelo Dr. Francisco Xavier da Silva, Presidente do Estado ao installar-se a $2^{a}$ sessão da $10^{a}$ Legislatura em $1^{\circ}$ de fevereiro de 1911. Curityba: Typografia d'A Republica, 1911, p. 11.

STAUFFER, David Hall. Origem e fundação do Serviço de Proteção aos Índios. Revista de História, São Paulo: USP, vol. 20, p. 37 a 44.1959/1960.

TOMMASINO, K; MOTA, L. T.; NOELLI, F. S. (orgs.). Novas contribuições aos estudos interdisciplinares dos Kaingang. Londrina: Eduel, 2004.

TOMMASINO, Kimiye. A história dos Kaingang da Bacia do Tibagi: uma sociedade Jê meridional em movimento. Tese de Doutorado em Antropologia, USP, 1995.

TOMMASINO, Kimiye. Território e territorialidade Kaingang: resistência cultural e historicidade de um grupo Jê. IN: Uri e Waxi. Londrina: Eduel, 2001.

TRIGGER, Bruce G. Etnohistoria: problemas y perspectivas. San Juan: Universidad Nacional de San Juan, 1987.

VAL FLORIANA, Mansueto Barcatta de. Diccionarios Kainjgang-Portuguez e PortuguezKainjgang composto pro Frei Mansueto Barcatta de Val Floriana da ordem dos missionários capuchinhos do estado de São Paulo. Revista do Museu Paulista. São Paulo: Typ do Diário Oficial, vol. 12, p. 1-392.1920.

VARGAS, Túlio. O Indomavel Republicano. Curitiba: O Formigueiro, 1970.

VARGAS, Túlio. O Maragato - a vida lendária de Telêmaco Borba. Curitiba: Jurua, 2001.

WOLF, Eric R. Europa y la gente sin historia. México: Fondo de Cultura Economica, 2005.

Texto recebido em 11 de setembro de 2013 e aprovado em 17 de maio de 2014 